J Biol Inorg Chem. 2018 August ; 23(6): 903-916. doi:10.1007/s00775-018-1589-x.

\title{
Targeting the mitochondrial VDAC in hepatocellular carcinoma using a polyclonal antibody-conjugated to a nitrosyl ruthenium complex
}

\author{
Loyanne C. B. Ramos ${ }^{1}$, Fernando P. Rodrigues ${ }^{1}$, Juliana C. Biazzotto ${ }^{1}$, Sergio de Paula \\ Machado $^{2}$, Leonardo D. Slep ${ }^{3}$, Michael R. Hamblin ${ }^{4,5}$, and Roberto S. da Silva ${ }^{1,4,5}$ \\ ${ }^{1}$ Departamento de Física e Química, Faculdade de Ciências Farmacêuticas de Ribeirão Preto, \\ Universidade de São Paulo, Ribeirão Preto, SP, Brazil \\ ${ }^{2}$ Instituto de Química, Universidade Federal do Rio de Janeiro, Rio de Janeiro, RJ 21941-590, \\ Brazil \\ ${ }^{3}$ Departamento de Química Inorgánica, Analítica y Química Física and INQUIMAE, CONICET, \\ Facultad de Ciencias Exactas y Naturales, Universidad de Buenos Aires, Pabellón 2, Ciudad \\ Universitaria, C1428EHA Buenos Aires, Argentina \\ ${ }^{4}$ Wellman Laboratories of Photomedicine, Massachusetts General Hospital, Boston, MA 02114, \\ USA \\ ${ }^{5}$ Department of Dermatology, Harvard Medical School, Boston, MA 02115, USA
}

\begin{abstract}
The rational design of anti-cancer agents includes a new approach based on ruthenium complexes that can act as nitric oxide (NO) donor agents against specific cellular targets. One of the most studied classes of those compounds is based on bis(bipyridine) ruthenium fragment and its derivative species. In this work, we present the chemical and cytotoxicity properties against the liver hepatocellular carcinoma cell line HepG2 of cis-[Ru$\left.{ }^{\mathrm{II}}\left(\mathrm{NO}^{+}\right) \mathrm{Cl}(\mathrm{dcbpy})_{2}\right]^{2-}$ conjugated to a polyclonal antibody IgG (anti-VDAC) recognizing a cell surface marker. UV-visible bands of the ruthenium complex were assigned with the aid of density functional theory, which also allowed estimation of the structures that explain the biological effects of the ruthenium complex-IgG conjugate. The interaction of $c i s-\left[\mathrm{Ru}^{\mathrm{II}}\left(\mathrm{NO}^{+}\right) \mathrm{Cl}(\mathrm{dcbpy})_{2}\right]^{3-}$ with mitochondria was evaluated due to the potential of these organelles as anti-cancer targets, and considering they interact with the anti-VDAC antibody. The cytotoxicity of $c i s-\left[\mathrm{Ru}^{\mathrm{II}}\left(\mathrm{NO}^{+}\right) \mathrm{Cl}(\mathrm{dcbpy})_{2}\right]^{3-}$-anti-VDAC antibody was up to $80 \%$ greater in comparison to the free $c i s-\left[\mathrm{Ru}^{\mathrm{II}}\left(\mathrm{NO}^{+}\right) \mathrm{Cl}(\mathrm{dcbpy})_{2}\right]^{3-}$ complex. We suggest that this effect is due to site-specific interaction of the complex followed by NO release.
\end{abstract}

Roberto S. da Silva, silva@usp.br; Michael R. Hamblin, hamblin@helix.mgh.harvard.edu.

Electronic supplementary material The online version of this article (https://doi.org/10.1007/s00775-018-1589-x) contains supplementary material, which is available to authorized users. 


\section{Keywords}

Nitrosyl ruthenium complexes; Conjugated ruthenium-antibody complex; Nitric oxide delivery agent

\section{Introduction}

In the last decade, there has been growing interest in the physiology of nitric oxide (NO) which has led to the development of a variety of new NO donors [1-7]. Metal-based compounds are one of the most promising classes of NO donor agents. Among these compounds, nitrosyl ruthenium complexes are the most studied and best understood species $[4,5,8-21]$.

In general, these complexes have the structure $\{\mathrm{Ru}-\mathrm{NO}\}^{3+}$, and they can act as NO delivery agents via (a) a reduction process [12, 15-17], (b) via direct light irradiation on the metalligand charge transfer band $\mathrm{d} \pi\left(\mathrm{Ru}^{\mathrm{II}}\right)-\pi^{*}\left(\mathrm{NO}^{+}\right)[16,17]$, or $(\mathrm{c})$ by photoinduced electron transfer $[20,21]$. Depending on the $\mathrm{pH},\{\mathrm{Ru}-\mathrm{NO}\}^{3+}$ can be fully converted to $\left\{\mathrm{Ru}-\mathrm{NO}_{2}\right\}^{+}$, which could act as an NO delivery agent either by photolysis or by an oxygen transfer reaction, as described in the literature $[16,22]$. The $d \pi\left(\mathrm{Ru}^{\mathrm{II}}\right)-\pi^{*}\left(\mathrm{NO}^{+}\right)$backbonding strongly influences the formation of the nitro compound [22].

For example, in the case of the complex cis- $\left[\mathrm{Ru}\left(\mathrm{NO}_{2}\right)(\mathrm{bpy})_{2} \mathrm{~L}\right]^{\mathrm{n}+/ 0}\left(\mathrm{~L}=\mathrm{Cl}^{-}\right.$, pyridine, isonicotinamide, 4-picoline, or 4-acetylpyridine), and where bpy is bipyridine (a strong $\pi$ acceptor ligand), cis-[Ru $\left.{ }^{\mathrm{II}}\left(\mathrm{NO}^{+}\right)(\mathrm{bpy})_{2} \mathrm{~L}\right]^{\mathrm{n}+1}$ is formed when the complex is dissolved in aqueous solution at $\mathrm{pH} \leq 4.0$ [5]. This may pave the way for the application of this kind of system in bioassays, which are usually conducted in physiological $\mathrm{pH}$. Regarding in vitro and in vivo assays, NO delivery agents based on ruthenium complexes have been used for a number of biological purposes [4] including experiments on vasorelaxation [22], Chagas disease [23-25], and cytotoxicity [12-15]. Maybe the most appealing feature is the possibility to control the amount of $\mathrm{NO}$ release based on the uptake of ruthenium species. For example, in cancer cells, NO has been suggested to modulate several different events $[26,27]$. It seems to show dual functionality: NO can be anti- or pro-tumorigenic depending on its local concentration [26]. NO levels between 50 and $100 \mathrm{nM}$ activate signal transduction pathways that elicit tumorigenic effects; above this level, NO exerts antitumoral functions [26]. The key to maximize the efficacy and/or reduce the side effects associated with NO, is better targeted delivery of these agents to tumor sites. Several strategies have been used in this way mainly focus in drug delivery system [28-34]. Although targeting NO delivery agents can promote an increase in cellular uptake, it may reduce overall cytotoxicity since certain threshold levels of NO over large areas may be required for activation of signaling pathways. Effective targeted NO delivery agents based on ruthenium complexes may improve local NO concentration, which could increase the cytotoxic effect of the nitric oxide derivative ruthenium complex. Compounds containing ruthenium(II) and some unsaturated ligands " $\mathrm{L}$ " show good stability mainly due to existing backbonding $\mathrm{d} \pi\left(\mathrm{Ru}{ }^{\mathrm{II}}\right)-$ $\pi^{*}(\mathrm{~L})$, and have been used as models in kinetic and photochemical studies [35, 36]. One class of compounds, for example, $\left[\mathrm{Ru}^{\mathrm{II}}(\mathrm{bpy})_{2} \mathrm{~L}\left(\mathrm{NO}^{+}\right)\right]^{\mathrm{n}+}$ has been studied due to its thermal 
stability, and also its ability to release NO under external stimulation $[4,9,10,13,14,37-$ 40]. This suggests these compounds might find applications as NO delivery agents and possible anti-cancer agents. One possible target within cancer cells is mitochondria. In addition to providing cellular energy, these organelles play an important role in cell signaling events, including those involving cell death [41]. The voltage-dependent anion channel (VDAC) is a protein in the mitochondrial outer membrane, controlling cross-talk between mitochondria and the remainder of cell. VDAC plays a central role in mitochondriamediated apoptosis by means of reactive oxygen species (ROS) generation, and it should be noted that NO can increase ROS levels [41]. Therefore, VDAC is a potential target for NO donor agents based on ruthenium complexes.

To achieve this goal, one approach to improve the molecular specificity of the ruthenium complex is by attaching it to a ligand that recognizes a surface marker that is preferentially expressed in cancer cells. Such strategy has been used for some ruthenium complexes [42, 43]. Hence, this work aimed to evaluate the cytotoxic effect of polyclonal antibody IgG, anti-VDAC conjugated to the nitrosyl ruthenium complex cis-[Ru(NO)Cl(dcbpy $\left.)_{2}\right]^{3-}$ where dcbpy is $2,2^{\prime}$-bipyridine- $4,4^{\prime}$-dicarboxylic acid as a NO delivery agent against the hepatocellular carcinoma cell line (HepG2).

\section{Materials and methods}

\section{Chemical and reagents}

$\mathrm{RuCl}_{3} \cdot \mathrm{nH}_{2} \mathrm{O}$, sodium nitrite, triethanolamine, $N, N^{\prime}$-dicyclohexylcarbodiimide (DCC), and $N$-hydroxysuccinimide (NHS) were purchased from Sigma-Aldrich Chemicals (Brazil) as high purity reagents. VDAC 1/2/3, FL-238, and rabbit polyclonal $\operatorname{IgG}\left(200 \mu \mathrm{g} \mathrm{mL}{ }^{-1}\right)$ were acquired from Santa Cruz Biotechnology (Santa Cruz, USA). Doubly distilled water was used in all experiments. Nitric oxide was prepared by the reaction of nitric oxide with copper turnings and was purified according to the literature method [37].

\section{Apparatus}

The ultraviolet-visible (UV-Vis) spectra were recorded on an Agilent 8453 spectrophotometer; the samples were placed in a quartz cell with an optical path length of 1 $\mathrm{cm}$. The infrared spectra were acquired on a Prestige 21 Schimadzu FTIR spectrometer; the samples were pressed into $\mathrm{KBr}$ pellets.

The $\mathrm{pH}$ was measured with a DM $20 \mathrm{pH}$ meter (Digimed). The photochemical experiments were carried out in aqueous solution containing the ruthenium complex at $1.0 \times 10^{-4} \mathrm{M}$. A 447-nm Diode Laser Colibri (Quantum Tec $^{\circledR}$ ) was employed. The electrochemical studies were performed in aqueous solution using an AUTOLAB PGSTAT 30 potentiostat/ galvanostat. A conventional three-electrode cell arrangement consisting of a glassy carbon disk working electrode, a platinum wire auxiliary electrode, and an $\mathrm{Ag} / \mathrm{AgCl}$ reference electrode was employed. The supporting electrolyte was $\mathrm{KCl}$ at $0.1 \mathrm{~mol} \mathrm{~L}^{-1}$.

NO was measured on a Dual Channel Nitric Oxide Measuring system inNO-T equipped with a selective amperometric sensor amiNO-600 from Innovative Instruments, Inc. Mass 
spectrometry was accomplished on an ULTROTOFQESI-TOF Mass Spectrometer (Bruker Daltonics, Billerica, USA) operating in the positive mode.

\section{Computational methodology}

Density functional theory (DFT) computations were employed to fully optimize the ground state geometries of all the species described in this work. The calculations were done with Gaussian 09 using Becke's three-parameter hybrid functional with the correlation functional of Lee, Yang and Parr formalized as the B3LYP hybrid functional [44-47] and the effective core potential basis set LanL2DZ [48-51], which proved to be suitable for geometry predictions in coordination compounds containing metals of the second row of the transition elements in the periodic table. Different degrees of protonation of the carboxylate groups in the dcbpy ligand were explored. The non-equivalency of the $-\mathrm{CO}_{2}{ }^{-}$groups of the molecule renders four different possibilities for monoprotonation and six possible combinations for diprotonation. In addition, the carboxylato groups can be engaged in solute-solvent hydrogen-bonding specific interactions, which have to be taken into account to avoid artifacts in the computations arising from the excess of negative charge on the $\mathrm{CO}_{2}{ }^{-}$ substituents. For this purpose, four explicit water molecules were incorporated in the geometry optimizations and all subsequent computations. All the different cases of monoand diprotonated structures plus the fully deprotonated molecule were fully optimized in vacuo. Tight SCF convergence criteria and default setting were used along the geometry optimizations. In all cases, vibrational analyses prove that the stationary points reached along the optimizations correspond to local minima in the potential energy surface. The computations suggest that whereas the monoprotonated stage is dominated by one single species, several isomers might contribute in significant proportions to the diprotonated species. The analysis of the electronic structure was complemented with (TD)DFT computations including at least 90 states of the same multiplicity than the ground state. The spectra were computed at the gas phase geometry. Apart from the explicit water molecules solvation effects in aqueous solution were incorporated in the computations employing the PCM approximation, as implemented in Gaussian 09.

\section{Synthesis of cis-[Ru(NO)Cl(dcbpy-H $\left.)_{2}\right]$}

The complex cis-[Ru(NO)Cl(dcbpy-H $\left.)_{2}\right]$ (Ru-DCBPY) was synthesized according to a previously similar published procedure [21]. The complex cis- $\left[\mathrm{RuCl}_{2}\left(\mathrm{dcbpy}-\mathrm{H}_{2}\right)_{2}\right]$ was the starting material; it was prepared in the same way as cis-[ $\left[\mathrm{RuCl}_{2}(\mathrm{bpy})_{2}\right] \cdot 2 \mathrm{H}_{2} \mathrm{O}$, described in [38]. Briefly, cis-[ $\left.\mathrm{RuCl}_{2}\left(\mathrm{dcbpy}-\mathrm{H}_{2}\right)_{2}\right] \cdot 2 \mathrm{H}_{2} \mathrm{O}(0.100 \mathrm{~g}, 0.14 \mathrm{mmol})$ was dissolved in $25 \mathrm{~mL}$ of milli-Q $\mathrm{H}_{2} \mathrm{O}$ and degassed with argon for $30 \mathrm{~min}$. Gaseous $\mathrm{NO}$ was then generated by reaction between nitric acid solution (50\% V/V) and metallic copper. The produced gaseous mixture was passed through a concentrated $\mathrm{NaOH}$ solution to eliminate $\mathrm{NO}_{2}$ traces. The nitric oxide was then bubbled through the cis-[ $\left[\mathrm{RuCl}_{2}\left(\mathrm{dcbpy}-\mathrm{H}_{2}\right)_{2}\right] \cdot 2 \mathrm{H}_{2} \mathrm{O}$ complex solution for $40 \mathrm{~min}$ to give a reddish-brown solution. This procedure was repeated three times for 24 $\mathrm{h}$ under constant stirring. The resulting brown precipitate was collected by filtration, washed with $30 \mathrm{~mL}$ of diethyl ether, and stored under vacuum in the dark. Yield: 59\% (Anal. calc. for $\mathrm{C}_{24} \mathrm{H}_{22} \mathrm{~N}_{5} \mathrm{O}_{13} \mathrm{ClRu}$ : C, 39.76; H, 3.06; N, 9.66. Found: C, 39.31; H, 2.96; N, 9.51\%). $\mathrm{m} / z=652.95\left(\left\{\left[\mathrm{Ru}(\mathrm{NO}) \mathrm{Cl}(\mathrm{dcbpy}-\mathrm{H})_{2}\right]\right\}^{+}\right)$. 


\section{Isolation of rat liver mitochondria}

Mitochondria were isolated by standard differential centrifugation [52]. Male Wistar rats weighing approximately $200 \mathrm{~g}$ were killed by decapitation, according to research protocols approved by CEUA-USP, Rib. Preto. Livers (10-15 g) were immediately removed, sliced in medium ( $50 \mathrm{~mL}$ ) consisting of $250 \mathrm{mM}$ sucrose, $1 \mathrm{mM}$ ethyleneglycolbis( $\beta$-aminoethyl)$N, N, N^{\prime}, N^{\prime}$-tetraacetic acid (EGTA), and $10 \mathrm{mM}$ 4-(2-hydroxyethyl)-1piperazineethanesulfonic acid (HEPES)-KOH, $\mathrm{pH} 7.2$, and homogenized three times for 15 $\mathrm{s}$, at 1-min intervals, with a Potter-Elvehjem homogenizer. Homogenate was centrifuged $(580 \mathrm{~g}, 5 \mathrm{~min})$, and the resulting supernatant was centrifuged further $(10,300 \mathrm{~g}, 10 \mathrm{~min})$. Pellets were then suspended in medium $(10 \mathrm{~mL})$ consisting of $250 \mathrm{mmol} \mathrm{L}^{-1}$ sucrose, 0.3 mM EGTA, and $10 \mathrm{mM}$ HEPES-KOH, pH 7.2, and centrifuged (3400g, $15 \mathrm{~min})$. The final mitochondrial pellet was suspended in medium $(1 \mathrm{~mL})$ consisting of $250 \mathrm{mM}$ sucrose and 10 mM HEPES-KOH, $\mathrm{pH} 7.2$, and used within $3 \mathrm{~h}$. Mitochondrial protein content was determined by the Biuret reaction. For the assays, mitochondria $\left(0.5\right.$ or $1 \mathrm{mg}$ protein $\left.\mathrm{mL}^{-1}\right)$ were energized with $5 \mathrm{mM}$ potassium succinate (plus $2.5 \mu \mathrm{M}$ rotenone) in a standard medium consisting of $125 \mathrm{mM}$ sucrose, $65 \mathrm{mM} \mathrm{KCl}$, and $10 \mathrm{mM}$ HEPES-KOH, pH 7.4, at $30{ }^{\circ} \mathrm{C}$.

\section{Direct detection of NO release from complex (Ru-DCBPY)}

NO release from complex (Ru-DCBPY) $(100 \mu \mathrm{M})$ after incubation with succinate-energized mitochondria $\left(1 \mathrm{mg}\right.$ protein $\left.\mathrm{mL}^{-1}\right)$ in standard medium was assessed with a Selective Sensor Electrode (AmiNO 700) in the dark.

\section{Mitochondrial assays}

Mitochondrial oxygen consumption was monitored in the standard medium, in an oxygraph equipped with a Clark-type oxygen electrode (Hansatech instruments, oxytherm electrode unit, UK). Mitochondrial membrane potential was estimated spectrofluorimetrically; $10 \mu \mathrm{M}$ of cationic dye safranine $O$ was used as probe and fluorescence was measured at 495/586 $\mathrm{nm}$ excitation/emission wavelength pair [53]. ROS/RNS levels were evaluated by monitoring oxidation of dichlorodihydrofluorescein diacetate $\left(\mathrm{H}_{2} \mathrm{DCFDA}\right)$ (Molecular Probes, Eugene) at the 503/528 nm excitation/emission wavelength pair [54]. The fluorimetric experiments were accomplished on a Hitachi Model F-4500 spectrofluorimeter (Tokyo, Japan).

Mitochondrial swelling was estimated from the decrease in the apparent absorbance at 540 $\mathrm{nm}[55]$.

\section{Synthesis of cis-[RuCl(dcbpy $\left.)_{2}\left(\mathrm{NO}_{2}\right)\right]^{4-}$-anti-VDAC}

The porin antibody anti-VDAC was bound to the (Ru-DCBPY) forming cis-[RuCl $\left.(\text { dcbpy })_{2}\left(\mathrm{NO}_{2}\right)\right]^{4-}$-anti-VDAC via amide bond formation using a procedure similar to the procedure described by Terpetsching et al. [56]. In this protocol, DCC $(0.230 \mathrm{~g}, 1.11 \mathrm{mM})$ and NHS $(0.119 \mathrm{~g}, 1.030 \mathrm{mM})$ were dissolved in dimethylformamide $(3.0 \mathrm{~mL})$, under stirring, and cooled in an ice bath. Next, (Ru-DCBPY) $(0.200 \mathrm{~g}, 2.53 \mathrm{mM})$ was added, and the mixture was stirred for $2 \mathrm{~h}$. The precipitate was removed by filtration through a syringe filter (Millipore-Millex $0.22 \mu \mathrm{m})$. The filtrate $(500 \mu \mathrm{L})$ containing the active Ru complex was added to an $\operatorname{IgG}$ solution in $0.2 \mathrm{M}$ carbonate buffer $\mathrm{pH} 8.3(1.0 \mathrm{~mL}, 1 \% \operatorname{IgG})$ and stirred 
for $12 \mathrm{~h}$. Purification of the labeled protein was performed by gel filtration chromatography on Sephadex G-25 coupled to a peristaltic pump (GILSON, miniplus 3) at $1 \mathrm{~mL} \mathrm{~min}^{-1}$ flow; $0.1 \mathrm{M}$ phosphate buffer $\mathrm{pH} 7.2$ was used. The fractions were collected in a Fraction Collector LKB, BROMA.

\section{Antibody detection (western blotting) and (UV-Vis) assessment of fractions}

$\operatorname{IgG}$ (anti-VDAC) was determined in (aliquot) fractions by western blotting. The mitochondria harvested from aliquots obtained from the Sephadex column were resuspended in CelLytic ${ }^{\mathrm{TM} M}$ (Sigma, Brazil) lysis buffer for $2 \mathrm{~min}$, on ice, and centrifuged at $10,000 \mathrm{~g}$ for $5 \mathrm{~min}$. The resulting supernatants were subjected to $12 \%$ SDS-PAGE, transferred to a nitrocellulose membrane, and probed with antibodies against cytochrome $c$ (BD Pharmigen, purified mouse anticytochrome $c$ ) followed by horseradish peroxidasecoupled detection.

\section{HepG2 cell culture}

The HepG 2 cells were obtained from the American Type Culture Collection. The cell line was cultured in Dulbecco's medium supplemented with $10 \%$ fetal bovine fetal serum, 100 IU mL ${ }^{-1}$ penicillin G, $100 \mathrm{mg} \mathrm{mL}^{-1}$ streptomycin, and $1 \mu \mathrm{g} \mathrm{mL}^{-1}$ amphotericin. The cells were plated in 6, 12, 24 and 96-well plates and cultured until 75-90\% confluence was achieved (depending on the assay) in a humidified incubator at $37.0{ }^{\circ} \mathrm{C}$ with $5.0 \% \mathrm{CO}_{2}$.

\section{MTT cell viability assay}

The viability of the HepG2 cells was assessed by means of the [3-(4,5-dimethylthiazol-2yl)-2,5-diphenyl tetrazolium bromide] (MTT) colorimetric assay. The cells were plated on 96-well microtiter cell culture plates at $2 \times 10^{4}$ cells/well for $24 \mathrm{~h}$. After the indicated treatment, the cells were incubated at $37.0^{\circ} \mathrm{C}$ for $3 \mathrm{~h}$ in a culture medium containing $10 \mathrm{~mol}$ $\mathrm{L}^{-1}$ MTT in phosphate-buffered saline (PBS). The blue MTT formazan precipitate was then dissolved in $50 \mathrm{~L}$ of DMSO, and the absorbance was measured at $570 \mathrm{~nm}$ with a multi-well plate reader [57]. The cell viability was expressed as the percentage of the absorption values in the treated cells relative to the non-treated (control) cells. The data are presented as the means \pm the standard error of three independent experiments.

\section{Statistical analysis}

Statistical analysis was performed by two-way ANOVA. Equality of variance was assumed with Bonferroni's post hoc test for pairwise comparisons. Results with $P<0.05$ were considered statistically significant.

\section{Results and discussion}

NO bubbling through an aqueous cis- $\left[\mathrm{RuCl}_{2}\left(\mathrm{dcbpy}-\mathrm{H}_{2}\right)_{2}\right]$ solution afforded the nitrosyl ruthenium complex (Ru-DCBPY) in high yield. Elemental analyses of complex (RuDCBPY) as well as mass spectrum analysis (Supplementary material: Figure 1) agreed with the proposed molecular formula. Complex (Ru-DCBPY) displayed electronic absorption spectrum with poor defined bands at $323 \mathrm{~nm}(\log \varepsilon=3.97)$ and $305 \mathrm{~nm}(\log \varepsilon=4.13)$, which was assigned based on theoretical calculations. Figure 1 provides a schematic 
representation of the (Ru-DCBPY) complex, with the carboxylato groups labeled to assist in the discussion that follows. Table 1 compiles the most relevant DFT-computed structural parameters $(\mathrm{Ru}-\mathrm{N}$ and $\mathrm{N}-\mathrm{O}$ distances, $\mathrm{Ru}-\mathrm{N}-\mathrm{O}$ angle and $\mathrm{IR}$ frequencies) for the different cis- $\left[\mathrm{Ru}^{\mathrm{II}}\left(\mathrm{NO}^{+}\right) \mathrm{Cl}\left(\mathrm{dcbpy}-\mathrm{H}_{X}\right)_{2}\right]^{n}(n$ vary of $2+$ to -2$)$ species explored in this work.

The metric parameters are within the expectations for this kind of compounds, with slight differences depending on the presence or absence of explicit water molecules along the optimization procedure. In all cases, the $\mathrm{N}-\mathrm{O}$ bond length at ca. $1.19 \AA$ and the almost linear $\mathrm{Ru}-\mathrm{N}-\mathrm{O}$ moiety is consistent with a predominant $\mathrm{Ru}^{\mathrm{II}}-\mathrm{NO}^{+}$character. The computations predict NO stretching frequencies $\left(\nu_{\mathrm{NO}}\right)$ be insensitive to the protonation degree of the complex. Although the trans NO ligand has offered effect on the nitrosyl stretching frequency $[58,59]$, it seems to be not the case for nitrosyl bipyridine ruthenium complexes, in which a net effect for the $\sigma$-donor and $\pi$-acceptor character of different forms of carboxybipyridine ligand does not show significant change on the $v_{\mathrm{NO}}$ stretching frequency. Bipyridine nitrosyl ruthenium(II) complexes present $\nu_{\mathrm{NO}}$ stretching bands in the 1800-2000 $\mathrm{cm}^{-1}$. The peak intensity varies from medium to strong $[4,5,10,12-16,20,23,37-40,58-$ 60]. In the FTIR spectrum of (Ru-DCBPY) complex, $v_{\text {NO }}$ was found in $1945 \mathrm{~cm}^{-1}$ indicating that the complex is of $\left\{\mathrm{Ru}^{\mathrm{II}}-\mathrm{NO}^{+}\right\}^{6}$ type. In addition, the spectrum exhibits peaks at 1610,1560 and $1460 \mathrm{~cm}^{-1}$, which is characteristic of the pyridine rings. The carboxylate group is evidenced by a peak at $1690 \mathrm{~cm}^{-1}$. The calculated $\mathfrak{v}_{\mathrm{NO}}$ stretching frequencies for (Ru-DCBPY) in this work were $1800 \mathrm{~cm}^{-1}$, which are lower than the experimental ones. It is in part due to a tendency of DFT methods with standard functionals to provide too delocalized molecular and electronic structures due to inherent self-interaction errors [6163]. However, the inclusion of explicit water molecules at hydrogen-bonding distance of the carboxylato groups brings the $v_{\mathrm{NO}}$ values closer to the experimental ones. In the absence of these specific interactions, the high charge located on the $-\mathrm{CO}_{2}{ }^{-}$groups leads to several anomalies, not only in the stretching frequencies but also in the electronic structure picture and the predicted electronic spectroscopy. Even when isolated molecules have been included in the table for completeness, the following discussion will involve only hydrogen-bonded complexes.

There is no easy way to obtain by DFT reliable acidity constant values, which could assist in the determination of the degree of protonation in solution. The literature related to other species holding the $\left\{\mathrm{Ru}(\mathrm{dcbpy})_{2}\right\}^{2+}$ core suggests that, at the $\mathrm{pH}$ employed in our experiments, the nitrosyl species is probably best described as holding an average of two protonated carboxylato sites. Simple enthalpic arguments allow establishing that three out of the six possible diprotonated species present in solution (labeled 6-11 in Table 1) should predominate in acidic aqueous solution, with still non-negligible amounts of the remaining ones. The electronic structure and the (TD)DFT predicted spectra for all these species are in fact very similar, because the Ru-NO interaction dominates the orbital ordering. Figure 2 displays a MO diagram highlighting some relevant orbitals computed for isomer 6, expected to be the most abundant in solution.

The antibonding LUMO and LUMO + 1 orbitals have 22 and $25 \%$ contribution of metalcentered atomic orbitals, reflecting extensive mixing between the Ru d $\pi$ and the NO $\pi^{*}$ orbitals. This composition is comparable to other $\{\mathrm{RuNO}\}^{6}$ species and is consistent with a 
well-preserved nitrosonium character of the coordinated NO fragment. The high covalency of the $\mathrm{Ru}-\mathrm{NO}$ bond results in a noticeable stabilization of the $\mathrm{d} \pi$ orbitals, which leads to a HOMO that is mostly centered on the non-protonated carboxylato groups of the dcbp ligand. The occupied MOs immediately below the HOMO are also dcbpy, dcpyH $\mathrm{H}_{2}$ or $\mathrm{Cl}^{-}$centered and show little contribution from the Ru fragment. The HOMO-8 is the first MO with measurable $\mathrm{d} \pi \mathrm{Ru}$-centered contribution, and it is necessary to go as deep as HOMO-10 and HOMO-18 to find the bonding MOs that result from the interaction between the $\mathrm{d} \pi$ set and the nitrosyl ligand. This electronic picture results in an electronic spectrum, which is shifted to the high energy end of the visible region of the spectrum. In aqueous acidic medium, the

Ru-DCBPY was found to be light yellow in color exhibiting band at $305 \mathrm{~nm}$. The spectrum feature was similar to the data reported in the literature for nitrosyl ruthenium bipyridine [5, $14,17,21,22,37]$. Figure 3 compares the experimental and computed electronic spectra.

The individual six possible diprotonated species spectra show very subtle variations. Nevertheless, the differences in the absorption maxima for the six cases are within the error for the computational methodology, allowing to focus the analysis on one particular example without loss of generality. For the species number 6 (TD)DFT predicts the most intense absorption in the $250-800 \mathrm{~nm}$ to be centered at $315 \mathrm{~nm}$. This transition, which is mostly a ligand-to-ligand charge transfer transition between dcbpy $\mathrm{H}_{2}$ and $\mathrm{NO}^{+}$centered $\mathrm{MO}$ 's, accounts for the experimental absorption maximum at $305 \mathrm{~nm}$. The shoulder at lower energies originates in a series of closely spaced low intensity absorptions of similar origin involving any of the three dcbpy, dcpyH $\mathrm{H}_{2}$ or $\mathrm{Cl}^{-}$co-ligands. These transitions overlap with the usual $\pi-\pi^{*}$ absorptions due to the bipyridinic moieties. Finally, the experimental weak absorption band in the 450-500 $\mathrm{nm}$ region seems to involve transitions between orbitals in the range HOMO-7 to HOMO-14 and the NO-centered LUMO and LUMO + 1 orbitals and have mixed ligand to ligand and metal to ligand charge transfer character, revealing the existence of low lying excited states with $\mathrm{Ru}(\mathrm{III})-\mathrm{NO}(0)$ character.

In physiological $\mathrm{pH}, \mathbf{R u}-\mathrm{DCBPY}$ was slowly converted to $c i s-\left[\mathrm{RuCl}(\mathrm{dcbpy})_{2}\left(\mathrm{NO}_{2}\right)\right]^{4-}$ by nucleophilic attack of hydroxide ion (Scheme 2); $k_{\mathrm{obs}}$ was $5.35 \times 10^{-4} \pm 2.47 \times 10^{-5} \mathrm{~s}^{-1}$ at $25.0 \pm 0.1{ }^{\circ} \mathrm{C}$ (Supplementary Material: Figure 2). In $\mathrm{pH} \leq 2.0$, a precipitate starts to form, probably due protonation of all carboxylate substituent. In that condition, we are not being able to measure the $\mathrm{p} K_{\mathrm{a}}$ of bonded $4,4^{\prime}$-dicarboxilic acid. As judged by published $\mathrm{p} K_{\mathrm{a}}$ for some cis-[Ru(dcbpy- $\left.\left.\mathrm{H}_{2}\right)_{2} \mathrm{~L}_{2}\right]^{n+}[64]$, it is reasonable to assume three equilibriums depending on $\mathrm{pH}$ for cis- $\left[\mathrm{Ru}(\mathrm{NO}) \mathrm{Cl}\left(\mathrm{dcbpy}-\mathrm{H}_{2}\right)_{2}\right]^{2+}$ complex (Scheme 1). In physiological $\mathrm{pH}$, the best assumption for the molecular structure of the nitrosyl ruthenium complex discussed in this work is the existence of the equilibrium constant described in Eq. 3.

The electrochemistry of nitrosyl ruthenium complexes has been extensively studied in both aqueous and nonaqueous media $[37,39,65,66]$. In general, these complexes undergo two one-electron processes between -1.0 and $1.0 \mathrm{~V}$ vs. $\mathrm{Ag} / \mathrm{AgCl}$ centered on the nitrogen oxide derivative ligand [58].

Cyclic voltammogram (CV) measurements of (Ru-DCBPY) in aqueous solution $\mathrm{KCl} 0.1$ and $0.01 \mathrm{M}$ acetate buffer solution was made separately in two different scan windows to isolate redox events of interest. The first redox couple has $E_{1 / 2}=0.14 \mathrm{~V}(\mathrm{vs} . \mathrm{Ag} / \mathrm{AgCl}$ ) and 
is attributed to the redox process centered on the nitrosyl group $\left(\mathrm{NO}^{+/ 0}\right)$ when the $\mathrm{CV}$ was performed in a potential window of +0.4 to $-0.2 \mathrm{~V}$ for the negative scan at the scan rate of $100 \mathrm{mV} \mathrm{s}^{-1}$ at $25^{\circ} \mathrm{C}$. The ratio of the anodic $\left(E_{\mathrm{pa}}\right)$ and cathodic $\left(E_{\mathrm{pc}}\right)$ current peak heights decreases in slow scan rate consistent with a coupled chemical reaction. The results are in line with the loss of NO following reduction process of (Ru-DCBPY) as generally observed for nitrosyl ruthenium complexes [4, 5, 10-16, 22, 58, 65, 66]. A second peak attributed as irreversible process was observed at $E_{1 / 2}=-0.42 \mathrm{~V}$ (vs. $\mathrm{Ag} / \mathrm{AgCl}$ ), due to $\mathrm{NO}^{0 /-}$, when the $\mathrm{CV}$ was performed in a potential window of +0.4 to $-0.8 \mathrm{~V}$. In aqueous solution, $E_{1 / 2}$ for (Ru-DCBPY) couples shifts $0.02 \mathrm{~V}$ to a higher potential in comparison to cis-[Ru(NO) $\left.\mathrm{Cl}(\text { bpy })_{2}\right]^{2+}$ due different $\sigma$-donor, $\pi$-acceptor character of co-ligands. It is consistent with the $c i s$ - $\left[\mathrm{Ru}(\mathrm{NO}) \mathrm{L}(\mathrm{bpy})_{2}\right]^{3+}$ series where the highest $\pi$-acceptor character of $\mathrm{L}$ changes the electrochemical process centered on nitrosyl ligand to higher values [67].

Chemical reduction of (Ru-DCBPY) in $0.015 \mathrm{M}$ ascorbic acid produced cis-[RuCl(dcbpy$\left.\mathrm{H})_{2}\left(\mathrm{H}_{2} \mathrm{O}\right)\right]^{-}$as judged by NO-sensor measurements (inset Fig. 4). Conducted spectroelectrochemistry at $0.1 \mathrm{~V} \mathrm{vs.} \mathrm{Ag} / \mathrm{AgCl}$ in $0.01 \mathrm{M} \mathrm{KCl} \mathrm{pH}=3.0$ controlled by the addition of $\mathrm{HCl}$ solution (Fig. 4) helped us to infer the electro-reduction process of the (RuDCBPY) species (Scheme 2).

The well-established electrochemical mechanism of (Ru-DCBPY) in aqueous solution may help to explain some biological results related to its use as NO delivery agent. Interaction sites for (Ru-DCBPY) in biological medium are cell/organelles membranes, which are also considered potential targets of anti-cancer drugs [16, 29, 41]. Among them, mitochondrial plays a critical role in numerous biochemical processes, particularly oxidative phosphorylation, process in which ATP synthesis is driven by the transfer of electrons from $\mathrm{NADH}$ and $\mathrm{FADH}_{2}$ along the respiratory chain in the inner mitochondrial membrane (IMM), to molecular oxygen. This process generates electrochemical proton gradient across the IMM used to drive the ATP synthesis via F1F0-ATP synthase. During this process, mitochondrial reactive oxygen species (ROS) are produced and may elicit the mitochondrial permeability transition (MPT) in association with $\mathrm{Ca}^{2+}$. MPT is a cyclosporine-(CsA)sensitive well-documented phenomenon mediated by the opening mitochondrial transition pores, which is related with cellular necrosis and cellular apoptosis [68-71]. Mitochondrial parameters, oxidative and bioenergetics provide perspectives for anti-cancer strategies. In this context, we have explored the effects of NO generated from ruthenium nitrosyl (RuDCBPY) on mitochondria.

First, we have determined the capability of succinate-energized isolated mitochondria induce NO release from (RU-DCBPY) using a selective electrode. Figure 5, in the gray area, shows time-course of direct determination of $\mathrm{NO}$ release suggesting that ruthenium complex underwent one-electron reduction centered on nitrogen oxide derivative ligand site, followed by NO release in the presence of mitochondrial NADH coenzyme. Previously, we demonstrated two similar mechanisms of NO release from ruthenium complexes of this same class, exposed to NADH $[12,16]$. NADH would bind directly to metal centers of ruthenium and ruthenium complexes, which suggests applicability of coenzyme. 


\section{Effects of complex (Ru-DCBPY) on mitochondrial reactive oxygen/nitrogen species (ROS/ RNS) levels and mitochondrial swelling}

The production of ROS/RNS by HepG2 cells after incubation with (Ru-DCBPY) was examined to provide evidence on cell death mechanisms involving mitochondria. Figure 6 shows increased ROS/RNS levels in succinate-energized mitochondria, incubated as indicated, through oxidation of the nonspecific probe $\mathrm{H}_{2}$ DFDA [54]. The mitochondrial permeability transition inhibitor cyclosporine A (CsA) partially inhibited the effect of NO released from complex (Ru-DCBPY) at $100 \mu \mathrm{M}$ (higher concentration).

NO released from complex (Ru-DCBPY) induced $\mathrm{Ca}^{2+}$-dependent/CsA-sensitive mitochondrial swelling at 10-100 $\mu \mathrm{M}$, which attested to NO involvement in the classic mitochondrial permeability transition (MPT) (Fig. 7), a process usually associated with ROS/RNS generation [71-74]. CsA almost completely inhibited swelling induced by complex (Ru-DCBPY) at $50 \mu \mathrm{M}$. The inhibition of swelling by 2-(4carboxyphenyl)-4,4,5,5-tetramethylimidazoline-1-oxyl-3-oxide (cPTIO), a NO scavenger, suggests that NO was the MPT inducer. We propose that in the presence of superoxide anion $\left(\mathrm{O}^{-}{ }_{2}\right)$ from mitochondria, $\mathrm{NO}$ generates peroxynitrite, which in turn, inhibits respiratory chain and elicits MPT [15, 16].

\section{Effects of NO released from complex (Ru-DCBPY) on mitochondrial membrane potential and mitochondrial respiration}

Respiratory control ratio (RCR: state 3/state 4 respiration rates) indicates the degree of mitochondrial coupling. Table 2 shows that complex (Ru-DCBPY) at 10 and $50 \mu \mathrm{M}$ decreased RCR values, whilst at $100 \mu \mathrm{M}$ it increased the values. High NO concentrations inhibited respiration probably because reaction between $\mathrm{NO}$ and superoxide generated peroxynitrite, an irreversible respiratory chain inhibitor [72-75]. In agreement with the RCR results, complex (Ru-DCBPY) decreased the mitochondrial membrane potential in a doseresponse manner (10-100 $\mu \mathrm{M})$ (Fig. 8). Mitochondria efficiently induced NO release from complex (Ru-DCBPY) in a controlled way, via an oxidation-reduction mechanism. We propose that, once released, NO inhibited respiratory chain and raised ROS levels inducing MPT; ROS levels could be even increased by MPT. According to Brown and Borutaite, NOinduced cell necrosis occurs via respiratory chain inhibition at site I and/or IV and via RNSor oxidant-induced signal transduction. DNA damage may activate mitochondrial pathway to apoptosis. RNS-induced MPT may induce both apoptosis and necrosis. Various mechanisms by which NO acts to kill different types of cancer, such as breast, cervical, gastric, colorectal, and head and neck, have been addressed. However, local NO concentration is the main factor involved.

\section{(Ru-DCBPY)-IgG conjugate}

Nitrosyl ruthenium complexes may constitute useful NO delivery agents in anti-cancer therapy because they allow for control of the local NO concentration. We hypothesized that conjugating the nitrosyl ruthenium complex (Ru-DCBPY) with antibody, in basic medium, might improve the specificity of the complex for the target action site. Antibody-drug conjugates (ADCs) have been extensively studied as a promising class of anti-cancer agents. Cell recognition by drugs and consequent binding of the drug to target cells potentially 
increase drug accumulation in the desired tissues and organs. In this proof-of-concept study, we considered a novel system involving polyclonal antibody IgG anti-VDAC, the mitochondrial voltage-dependent anion-selective channel, conjugated to complex (RuDCBPY). The aim is targeting drugs to mitochondria, an organelle with high levels of the reducer agent NADH. Complex (Ru-DCBPY) covalently bound to the IgG immunoglobulin through a coupling reaction illustrated in Scheme 3; a previously published procedure was employed [56].

The resulting complex (Ru-DCBPY)-IgG conjugate was purified in a Sephadex G-25 column. UV-Vis spectroscopy helped to identify the separated fractions containing the complex (Ru-DCBPY)-IgG conjugate. The eluted conjugates were analyzed by Western blotting. Figure 9 depicts the comparative cytotoxicity on the Hepg2 cell line induced by free VDAC, complex (Ru-DCBPY) and complex (Ru-DCBPY)-IgG conjugate. The viability of HepG2 cell decreased in the presence of selected fractions from the column separation, containing the conjugates (fractions 14-17) as compared to the control (cell culture medium only), free VDAC, $c i s-\left[\mathrm{RuCl}_{2}(\mathrm{dcbpy}-\mathrm{H})_{2}\right]$ and free (Ru-DCBPY). Cellular uptake measured for aqueous complex (Ru-DCBPY) was in the order of $10^{-8} \mathrm{~mol} \mathrm{~L}^{-1}$, which contained the (Ru-DCBPY)-IgG conjugate. Cytotoxicity was probably a consequence of interactions between the anti-VDAC antibody conjugate and the mitochondrial VDAC protein $[72,73]$.

In principle, the remaining complex (Ru-DCBPY) in the complex (Ru-DCBPY)-IgG conjugate underwent chemical reaction in the cancer cell membrane. This process could be attributed to the reduction of conjugated (Ru-DCBPY) or oxygen transfer reaction of cis$\left[\mathrm{RuCl}(\mathrm{dcbpy})_{2}\left(\mathrm{NO}_{2}\right)\right]^{4-}$ generating $\mathrm{NO}$, which may have reacted with superoxide to give peroxynitrite, a species that inhibits the mitochondrial respiration process by several biochemical pathways [16]. Typically, these mitochondrial events are involved in cell death and can potentially kill tumor cells.

\section{Conclusions}

The use of an antibody-nitrosyl ruthenium complex conjugate was shown to be able to kill the HepG-2 cancer cell line. Local NO release accounted for the observed cytotoxicity, which could be explained by the (Ru-DCBPY) complex targeting the mitochondrial VDAC where it undergoes reduction and NO release. Alterations of the NAD ${ }^{+} / \mathrm{NADH}$ redox couple have also been described as a new mechanism for anti-cancer drug activity, and may be involved in the cytotoxicity of the (Ru-DCBPY)-IgG conjugate.

\section{Supplementary Material}

Refer to Web version on PubMed Central for supplementary material.

\section{Acknowledgements}

This work was supported by CNPq, CAPES, FAPESP Grant 2016/08851-0 and scholarship 2009/11471-9 (Loyanne Ramos). MRH was supported by US NIH Grants R01AI050875 and R21AI121700, Air Force Office of Scientific Research Grant FA9550-13-1-0068, by US Army Medical Research Acquisition Activity Grant W81XWH-09-1-0514, and by US Army Medical Research and Materiel Command Grant W81XWH-13-2-0067. 


\section{References}

1. Miller MR , Megson IL (2007) Recent developments in nitric oxide donor drugs. Br J Pharmacol 151(3):305-32117401442

2. Bonavida B (ed) (2010) Nitric oxide (NO) and cancer: prognosis, prevention, and therapy. Springer Science and Business Media, New York

3. Serafim RA , Primi MC , Trossini GH , Ferreira EI (2012) Nitric oxide: state of the art in drug design. Curr Med Chem 19(3):386-40522335514

4. Tfouni E, Truzzi DR, Tavares A, Gomes AJ , Figueiredo LE, Franco DW (2012) Biological activity of ruthenium nitrosyl complexes. Nitric Oxide 26(1):38-5322178685

5. de Lima RG, Silva BR, da Silva RS , Bendhack LM (2014) Ruthenium complexes as NO donors for vascular relaxation induction. Molecules 19(7):9628-965425004072

6. Szabo C (2016) Gasotransmitters in cancer: from pathophysiology to experimental therapy. Nat Rev Drug Discovery 15:185-20326678620

7. Lundberg JO, Gladwin MT, Weitzberg E (2015) Strategies to increase nitric oxide signalling in cardiovascular disease. Nat Rev Drug Discov 14(9):623-64126265312

8. Paulo M , Banin TM , de Andrade FA, Bendhack LM (2014) Enhancing vascular relaxing effects of nitric oxide-donor ruthenium complexes. Future Med Chem 6(7):825-83824941875

9. Liu J , Duan Q, Wang J , Song Z, Qiao X, Wang H (2015) Photocontrolled nitric oxide release from two nitrosylruthenium isomer complexes and their potential biomedical applications. J Biomed Opt 20(1):01500425621873

10. Carneiro ZA , Biazzotto JC, Alexiou AD, Nikolaou S (2014) Nitric oxide photorelease from a trinuclear ruthenium nitrosyl complex and its in vitro cytotoxicity against melanoma cells. J Inorg Biochem 134:36-3824522147

11. Castro PFDS, Andrade DL, Reis CDF, Costa SHN, Batista AC, Silva RS, Rocha ML (2016) Relaxing effect of a new ruthenium complex nitric oxide donor on airway smooth muscle of an experimental model of asthma in rats. Clin Exp Pharmacol Physiol 43(2):221-22926662887

12. Rodrigues FP, Carneiro ZA , Mascharak P , Curti C , da Silva RS (2016) Incorporation of a ruthenium nitrosyl complex into liposomes, the nitric oxide released from these liposomes and HepG2 cell death mechanism. Coord Chem Rev 306:701-707

13. Ramos LCB , Marchesi MSP , Callejon D , Baruffi MD , Lunardi CN , Slep LD, Bendhack LM , da Silva RS (2016) Enhanced antitumor activity against melanoma cancer cells by nitric oxide release and photosensitized generation of singlet oxygen from ruthenium complexes. Eur J Inorg Chem 22:3592-3597

14. Negri LB , Martins TJ , Ramos LCB , da Silva RS (2017) Nitric oxide derivative ruthenium compounds as NO-based chemotherapeutic and phototherapeutic agents In: Sebara AB (ed) Nitric oxide donors: novel biomedical applications and perspectives, 1st edn Elsevier, New York, pp 124

15. Toledo JC, de França Lopes LG, Alves AA, da Silva LP , Franco DW (2002) Release of NO by a nitrosyl complex upon activation by the mitochondrial reducing power. J Inorg Biochem 89(3): 267-27112062131

16. Rodrigues FP, Pestana CR, Polizello AC, Pardo-Andreu GL, Uyemura SA, Santos AC, Alberici LC , da Silva RS , Curti C (2012) Release of NO from a nitrosyl ruthenium complex through oxidation of mitochondrial NADH and effects on mitochondria. Nitric Oxide 26(3):17418122349020

17. Pereira ADC , Ford PC , da Silva RS , Bendhack LM (2011) Ruthenium-nitrite complex as prodrug releases NO in a tissue and enzyme-dependent way. Nitric Oxide 24(4):192-19821440656

18. Fry NL, Mascharak PK (2011) Photoactive ruthenium nitrosyls as NO donors: how to sensitize them toward visible light. Acc Chem Res 44(4):289-29821361269

19. Smith NA, Sadler PJ (2013) Photoactivatable metal complexes: from theory to applications in biotechnology and medicine. Philos Trans R Soc A 371:20120519

20. da Silva RS , Marchesi MS , Khin C , Lunardi CN , Bendhack LM , Ford PC (2007) Photoinduced electron transfer between the cationic complexes $\left[\mathrm{Ru}\left(\mathrm{NH}_{3}\right)_{5} \mathrm{pz}\right]^{2+}$ and trans- 
$[\mathrm{RuCl}([15] \mathrm{aneN} 4) \mathrm{NO}]^{+}$mediated by phosphate ion: visible light generation of nitric oxide for biological targets. J Phys Chem B 111(24):6962-696817439277

21. Cicillini SA, Prazias ACL, Tedesco AC, Serra OA, da Silva RS (2009) Nitric oxide and singlet oxygen photo-generation by light irradiation in the phototherapeutic window of a nitrosyl ruthenium conjugated with a phthalocyanine rare earth complex. Polyhedron 28(13):2766-2770

22. Da Rocha ZN , Marchesi MSP , Molin JC, Lunardi CN , Miranda KM , Bendhack LM , Ford PC , da Silva RS (2008) The inducing NO-vasodilation by chemical reduction of coordinated nitrite ion in $c i s-\left[\mathrm{Ru}\left(\mathrm{NO}_{2}\right) \mathrm{L}(\mathrm{bpy})_{2}\right]^{2+}$ complex. Dalton Trans 32:4282-4287

23. Sarniguet C , Toloza J , Cipriani M , Lapier M , Vieites M , Toledano-Magaña Y, García-Ramos JC, Ruiz-Azuara L, Moreno V , Maya JD , Azar CO , Gambino D, Otero L (2014) Water-soluble ruthenium complexes bearing activity against protozoan parasites. Biol Trace Elem Res 159(1-3): 379-39224740394

24. Sesti-Costa R , Carneiro ZA, Silva MC, Santos M , Silva GK, Milanezi C, da Silva RS , Silva JS (2014) Ruthenium complex with benznidazole and nitric oxide as a new candidate for the treatment of chagas disease. PLoS Negl Trop Dis 8(10):3207

25. Iniguez E, Sánchez A, Vasquez MA, Martínez A, Olivas J, Sattler A, Sánchez-Delgado RA, Maldonado RA (2013) Metal-drug synergy: new ruthenium (II) complexes of ketoconazole are highly active against Leishmania major and Trypanosoma cruzi and nontoxic to human or murine normal cells. J Biol Inorg Chem 18(7):779-79023881220

26. Ridnour LA, Thomas DD, Switzer C, Flores-Santana W, Isenberg JS , Ambs S, Roberts DD, Wink DA (2008) Molecular mechanisms for discrete nitric oxide levels in cancer. Nitric Oxide 19(2):73-7618472020

27. Thomas DD , Ridnour LA, Isenberg JS , Flores-Santana W, Switzer CH, Donzelli S , Colton C, Harris CC , Roberts DD , Wink DA (2008) The chemical biology of nitric oxide: implications in cellular signaling. Free Radic Biol Med 45(1):18-3118439435

28. Stevens EV , Wells A, Shin JH , Liu J , Der CJ , Schoenfisch MH (2010) Nitric oxide-releasing silica nanoparticle inhibition of ovarian cancer cell growth. Mol Pharm 7(3):775-78520205473

29. Hirst D , Robson T (2007) Targeting nitric oxide for cancer therapy. J Pharm Pharmacol 59(1):31317227615

30. Xiang HJ , Deng Q, An L, Guo M, Yang SP, Liu JG (2016) Tumor cell specific and lysosometargeted delivery of nitric oxide for enhanced photodynamic therapy triggered by $808 \mathrm{~nm}$ nearinfrared light. Chem Commun 52(1):148-151

31. Park J , Pramanick S , Kim J , Leeab J , Kim WJ (2017) Nitric oxide-activatable gold nanoparticles for specific targeting and photo-thermal ablation of macrophages. Chem Commun 53(81):1122911232

32. Safdar S , Payne CA, Tu NH , Taite LJ (2013) Targeted nitric oxide delivery preferentially induces glioma cell chemosensitivity via altered p53 and O6-methylguanine-DNA methyltransferase activity. Biotechnol Bioeng 110(4):1211-122023125026

33. Li YH, Guo M, Shi SW , Zhang QL, Yang SP , Liu JG (2017) A ruthenium-nitrosylfunctionalized nanoplatform for the targeting of liver cancer cells and NIR-light-controlled delivery of nitric oxide combined with photothermal therapy. J Mater Chem B 5(38):7831-7838

34. Deng Q , Xiang HJ , Tang WW , An L, Yang SP , Zhang QL , Liu JG (2016) Ruthenium nitrosyl grafted carbon dots as a fluorescence-trackable nanoplatform for visible light-controlled nitric oxide release and targeted intracellular delivery. J Inorg Biochem 165:152-15827324826

35. Wyland KR , Hoffman EE , Jain A (2017) DNA interaction studies and photoinduced ligand exchange kinetics of a sterically strained Ruthenium(II) complex. Inorg Chim Acta 454:62-66

36. Campagna S , Puntoriero F, Nastasi F, Bergamini G , Balzani V (2007) Photochemistry and photophysics of coordination compounds: ruthenium In: Balzani V , Campagna S (eds) Photochemistry and photophysics of coordination compounds I. Springer, Berlin, pp 117-214

37. Sauaia MG, de Lima RG, Tedesco AC, da Silva RS (2005) Nitric oxide production by visible light irradiation of aqueous solution of nitrosyl ruthenium complexes. Inorg Chem 44(26):9946995116363866

38. Meyer TJ , Godwin JB (1971) Preparation of ruthenium nitrosyl complexes containing 2, 2' bipyridine and 1, 10-phenanthroline. Inorg Chem 10(3):471-474 
39. Sauaia MG, Oliveira FS , Tedesco AC, da Silva RS (2003) Control of NO release by light irradiation from nitrosyl-ruthenium complexes containing polypyridyl ligands. Inorg Chim Acta 355:191-196

40. Ghosh K , Kumar S , Kumar R (2011) Synthesis and characterization of a novel ruthenium nitrosyl complex and studies on photolability of coordinated NO. Inorg Chem Commun 14(1):146

41. Elmore S (2007) Apoptosis: a review of programmed cell death. Toxicol Pathol 35(4):49551617562483

42. Grau-Campistany A , Massaguer A, Carrion-Salip D , Barragán F , Artigas G , López-Senín P , Moreno V , Marchán V (2013) Conjugation of a Ru(II) arene complex to neomycin or to guanidinoneomycin leads to compounds with differential cytotoxicities and accumulation between cancer and normal cells. Mol Pharm 10(5):1964-197623510087

43. Wang T, Zabarska N, Wu Y, Lamla M, Fischer S, Monczak K, Ng DYW, Sven Rau S, Weil T (2015) Receptor selective ruthenium-somatostatin photosensitizer for cancer targeted photodynamic applications. Chem Commun 51:12552-12555

44. Becke ADJ (1988) Density functional calculations of molecular bond energies. J Chem Phys $84: 4524-4529$

45. Becke ADJ (1993) Density-functional thermochemistry. III. The role of exact exchange. J Chem Phys 98:5648-5652

46. Lee C, Yang W, Parr RG (1988) Development of the Colle-Salvetti correlation-energy formula into a functional of the electron density. Phys Rev B 37(2):785-789

47. Perdew JP (1986) Density-functional approximation for the correlation energy of the inhomogeneous electron gas. Phys Rev B 33:8822-8824

48. Dunning TH , Hay PJ (1976) Modern theoretical chemistry In: Schaefer HF (ed) Modern theoretical chemistry. Plenum, New York, pp 1-28

49. Hay PJ , Wadt WRJ (1985) Ab initio effective core potentials for molecular calculations. Potentials for the transition metal atoms Sc to Hg. J Chem Phys 82:270-283

50. Hay PJ , Wadt WRJ (1985) Ab initio effective core potentials for molecular calculations. Potentials for $\mathrm{K}$ to Au including the outermost core orbitals. J Chem Phys 82:299-310

51. Wadt WR , Hay PJJ (1985) Ab initio effective core potentials for molecular calculations. Potentials for main group elements Na to Bi. J Chem Phys 82:284-298

52. Pedersen PL, Greenawalt JW, Reynafarje B, Hullihen J, Decker GL, Soper JW, Bustamente E (1978) Preparation and characterization of mitochondria and submitochondrial particles of rat liver and liver-derived tissues. Methods Cell Biol 20:411-481151184

53. Åkerman KE, Wikström MK (1976) Safranine as a probe of the mitochondrial membrane potential. FEBS Lett 68(2):191-197976474

54. Wrona M, Patel K, Wardman P (2005) Reactivity of 2', $7^{\prime}$-dichlorodihydrofluorescein and dihydrorhodamine 123 and their oxidized forms toward carbonate, nitrogen dioxide, and hydroxyl radicals. Free Radic Biol Med 38(2):262-27015607909

55. Blondin GA, Green DE (1967) The mechanism of mitochondrial swelling. Proc Natl Acad Sci USA 58(2):612-6195233462

56. Terpetschnig E, Szmacinski H , Malak H , Lakowicz JR (1995) Metal-ligand complexes as a new class of long-lived fluorophores for protein hydrodynamics. Biophys J 68(1):342-3507711260

57. Mosmann T (1983) Rapid colorimetric assay for cellular growth and survival: application to proliferation and cytotoxicity assays. J Immunol Methods 65:55-636606682

58. Tfouni E, Krieger M , McGarvey BR, Franco DW (2003) Structure, chemical and photochemical reactivity and biological activity of some ruthenium amine nitrosyl complexes. Coord Chem Rev 236(1-2):57-69

59. Caramori GF , Frenking G (2007) The nature of the Ru-NO bond in ruthenium tetraammine nitrosyl complexes. Organometallics 26(24):5815-5825

60. Videla M, Jacinto JS , Baggio R, Garland MT, Singh P, Kaim W , Slep LD , Olabe JA (2006) Structure, spectroscopy, and electrophilic and nucleophilic reactivities of bound nitrosyl. Inorg Chem 45:8608-861717029371 
61. Cohen AJ , Mori-Sánchez P, Yang W (2008) Insights into current limitations of density functional theory. Science 321(5890):792-79418687952

62. Coropceanu V, Malagoli M, André JM , Brédas JL (2002) Charge-transfer transitions in triarylamine mixed-valence systems: a joint density functional theory and vibronic coupling study. J Am Chem Soc 124(35):10519-1053012197754

63. Renz M , Kaupp M (2012) Predicting the localized/delocalized character of mixed-valence diquinone radical anions. Toward the right answer for the right reason. J Phys Chem A 116(43): 10629-1063723025699

64. Shimidzu T , Iyoda T, Izaki K (1985) Photoelectrochemical properties of bis (2,2' -bipyridine) (4,4'-dicarboxy-2,2' -bipyridine) ruthenium(II) chloride. J Phys Chem 89(4):642-645

65. Borges SDS , Davanzo CU, Castellano EE, Zukerman-Schpector J , Silva SC, Franco DW (1998) Ruthenium nitrosyl complexes with $N$-heterocyclic ligands. Inorg Chem 37(11):2670267711670402

66. Calandreli I , Oliveira FD , Liang GG, da Rocha ZN , Tfouni E (2009) Synthesis and characterization of trans-[Ru(NO)Cl(L)$)_{4}\left(\mathrm{PF}_{6}\right)_{2}(\mathrm{~L}=$ isonicotinamide; 4-acetylpyridine $)$ and related species. Inorg Chem Commun 12(7):591-595

67. Sauaia MG, da Silva RS (2003) The reactivity of nitrosyl ruthenium complexes containing polypyridyl ligands. Transit Met Chem 28(3):254-259

68. Zoratti M, Szabò I (1995) The mitochondrial permeability transition. Biochim Biophys Acta 1241(2):139-1767640294

69. Halestrap AP (2009) What is the mitochondrial permeability transition pore. J Mol Cell Cardiol 46(6):821-83119265700

70. Petronilli V , Cola C, Massari S, Colonna R, Bernardi P (1993) Physiological effectors modify voltage sensing by the cyclosporin A-sensitive permeability transition pore of mitochondria. J Biol Chem 268(29):21939-219458408050

71. Petronilli V, Costantini P, Scorrano L, Colonna R, Passamonti S , Bernardi P (1994) The voltage sensor of the mitochondrial permeability transition pore is tuned by the oxidation-reduction state of vicinal thiols. Increase of the gating potential by oxidants and its reversal by reducing agents. $\mathrm{J}$ Biol Chem 269(24):16638-166427515881

72. Brown GC (2007) Nitric oxide and mitochondria. Front Biosci 12(6):1024-103317127357

73. Brown GC , Borutaite V (2001) Nitric oxide, mitochondria, and cell death. IUBMB Life 52(3-5): 189-19511798032

74. Kroemer G , Galluzzi L , Brenner C (2007) Mitochondrial membrane permeabilization in cell death. Physiol Rev 87(1):99-16317237344

75. Gogvadze V , Orrenius S , Zhivotovsky B (2009) Mitochondria as targets for chemotherapy. Apoptosis 14(4):624-64019205885 


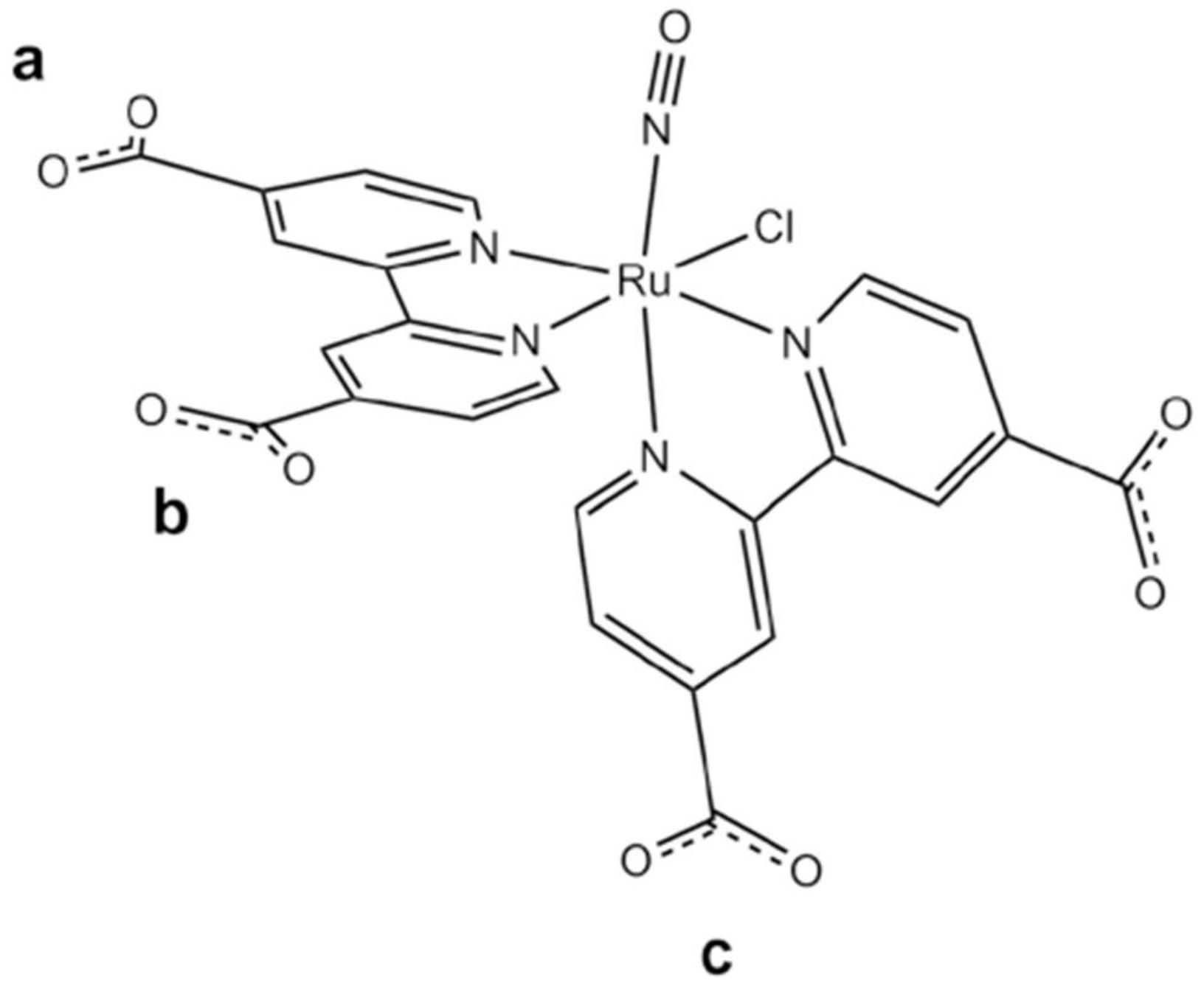

Fig. 1.

Schematic representation of the molecular structure of $c i s-\left[\mathrm{Ru}(\mathrm{NO}) \mathrm{Cl}(\mathrm{dcbpy})_{2}\right]^{2-}$ 


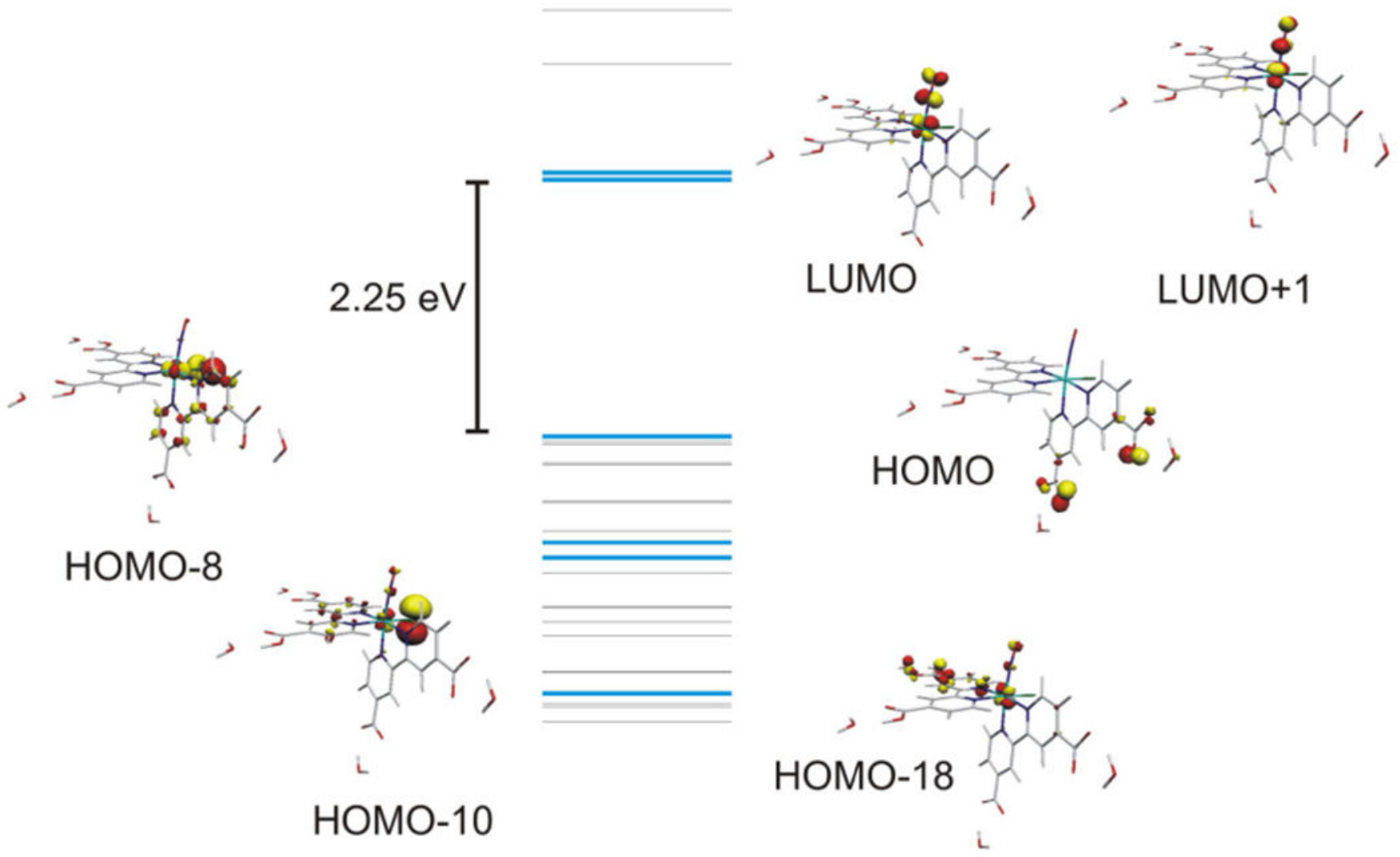

Fig. 2.

Molecular orbital diagram for species number 6 


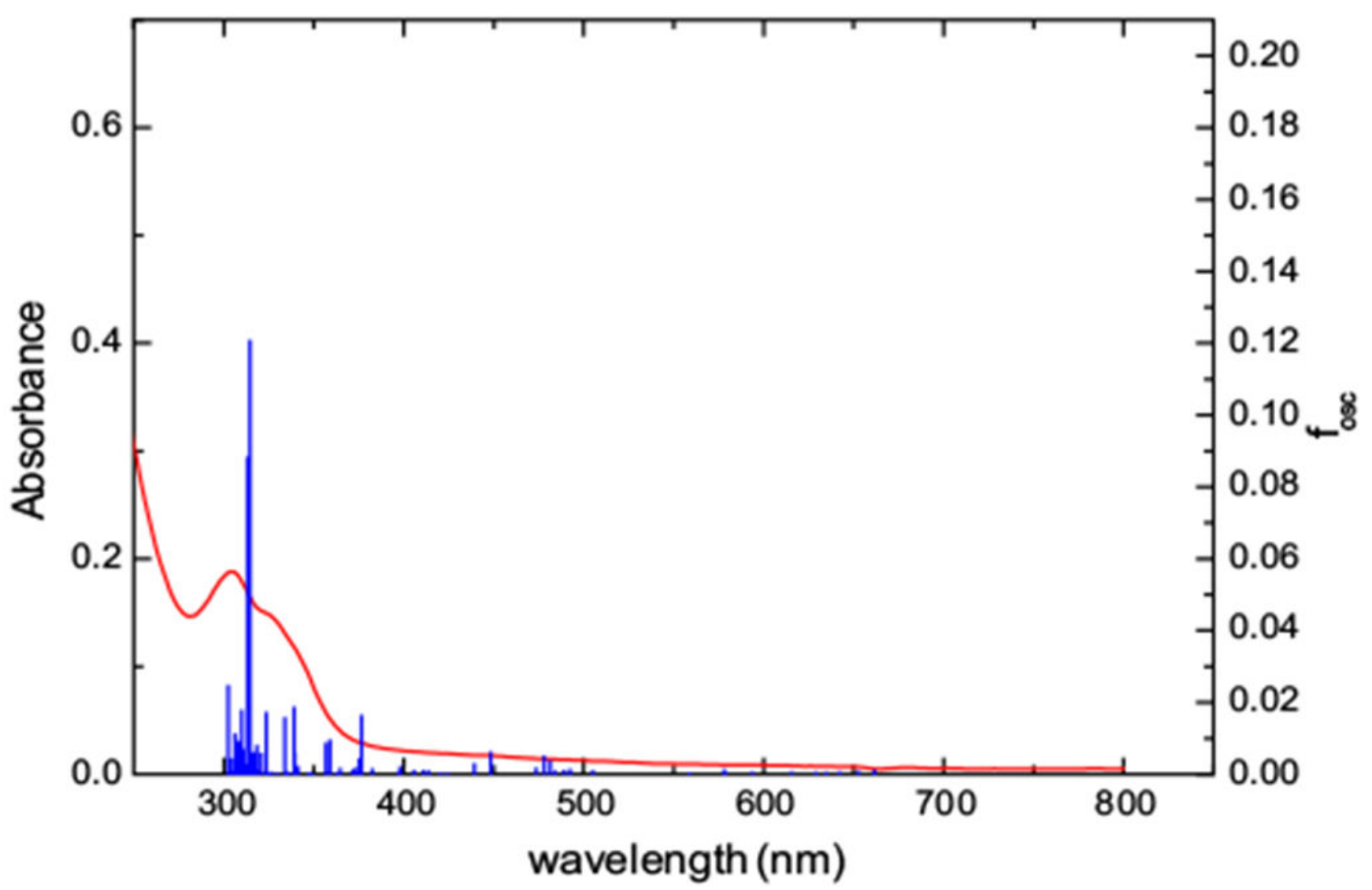

Fig. 3.

Experimental and (TD)DFT-computed spectra for $\left[\mathrm{Ru}(\mathrm{NO}) \mathrm{Cl}(\mathrm{dcbpy}-\mathrm{H})_{2}\right]$. The computed spectrum corresponds to species number 7 


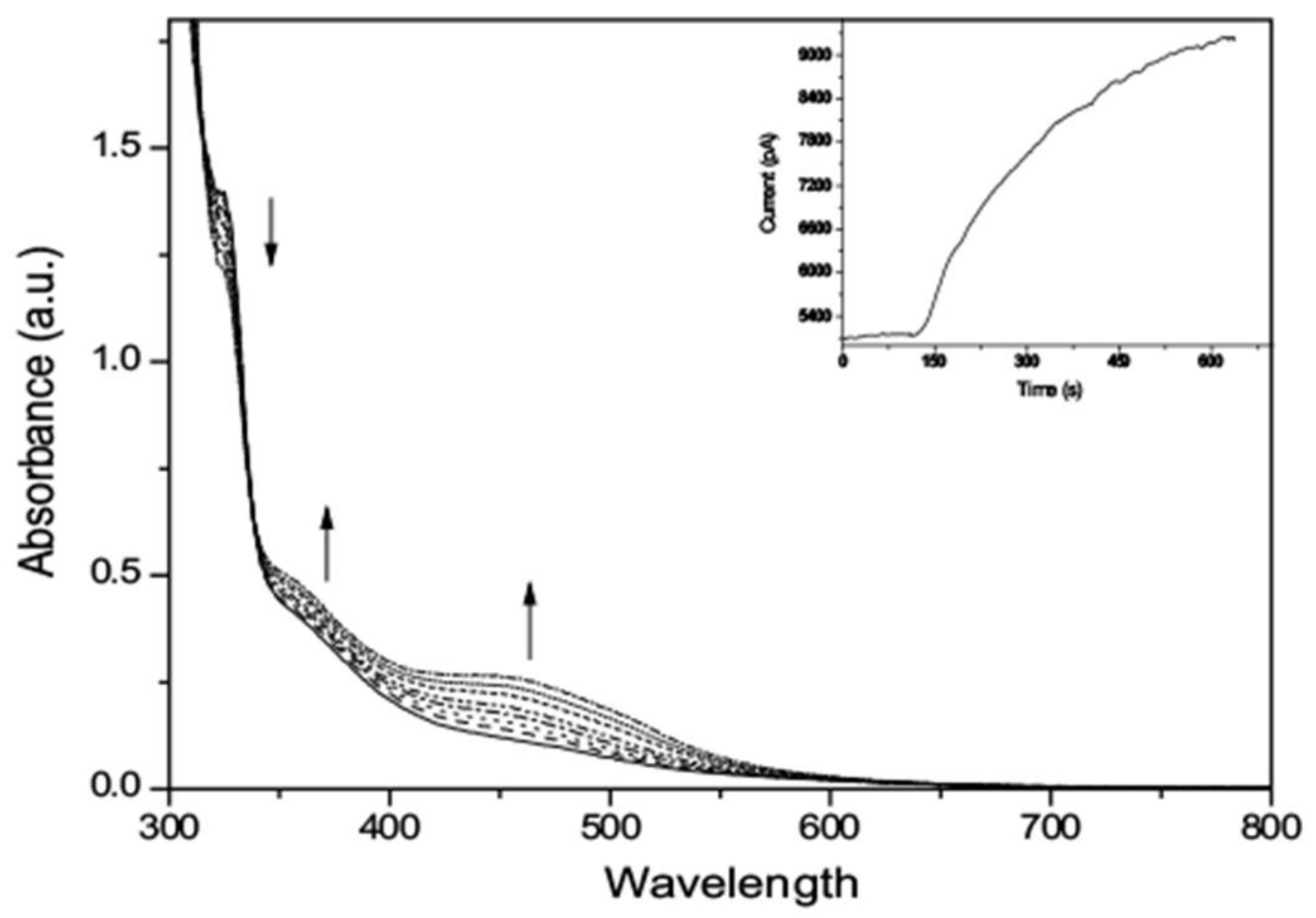

Fig. 4.

Spectroelectrochemistry measurements of (Ru-DCBPY) $\left(7.4 \times 10^{-5} \mathrm{M}\right)$ in aqueous $0.01 \mathrm{M}$ $\mathrm{KCl}$ solution, $\mathrm{pH}=3.0$. Inset: Chronoamperometry with $\mathrm{NO}$ sensor of aqueous ( $\mathbf{R u}-$

DCBPY) $\left(7.4 \times 10^{-5} \mathrm{M}\right)$ containing ascorbic acid $(0.015 \mathrm{M})$ 


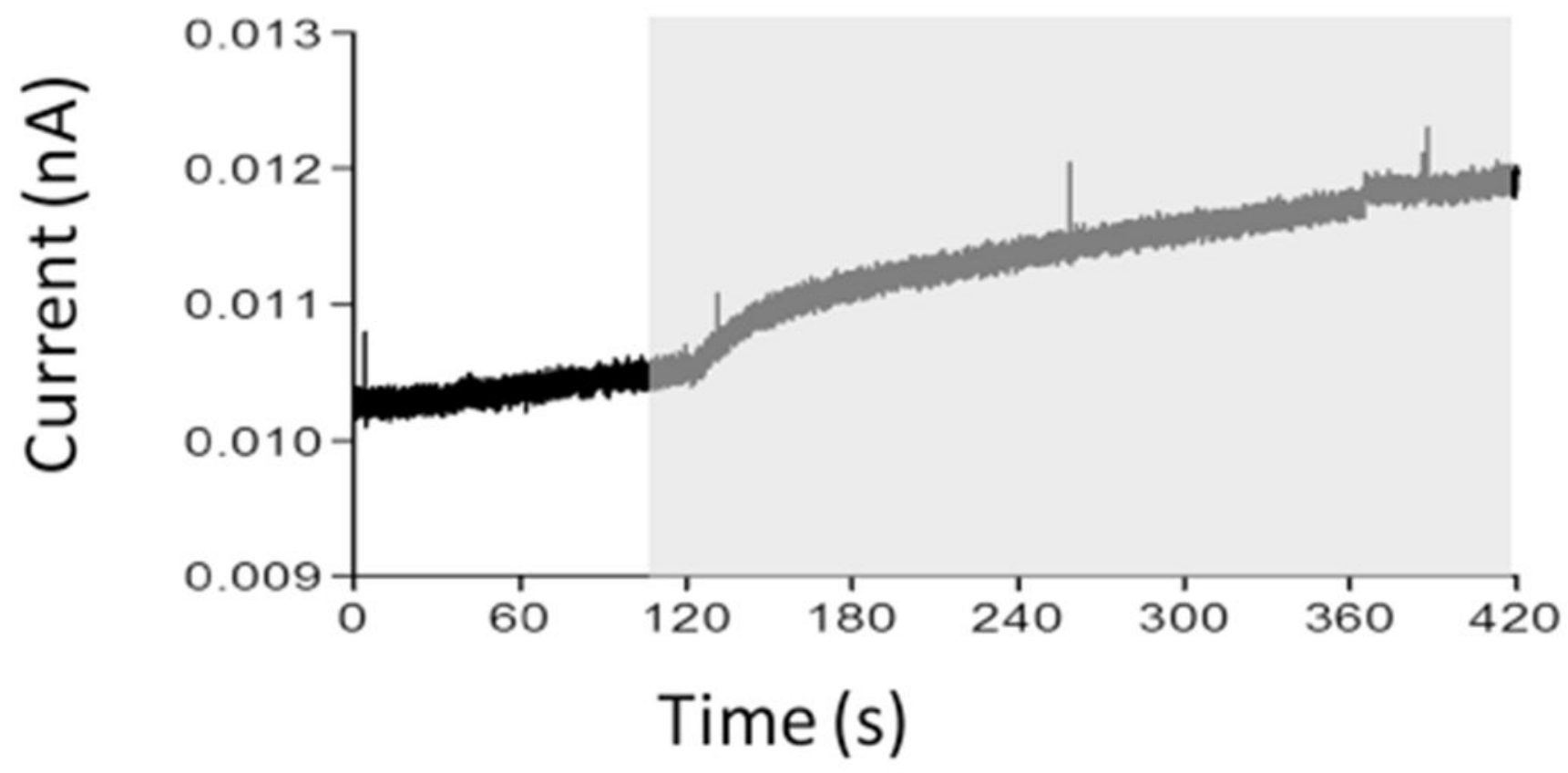

Fig. 5.

Release of NO from (Ru-DCBPY), evaluated by mitochondria-dependent oxy-reduction systems, detected directly through selective electrode. (Ru-DCBPY) $(100 \mu \mathrm{M})$ was incubated with mitochondria in standard medium. The plot, representative of three independent experiments, shows NO release. Gray area shows time course after mitochondria addition 


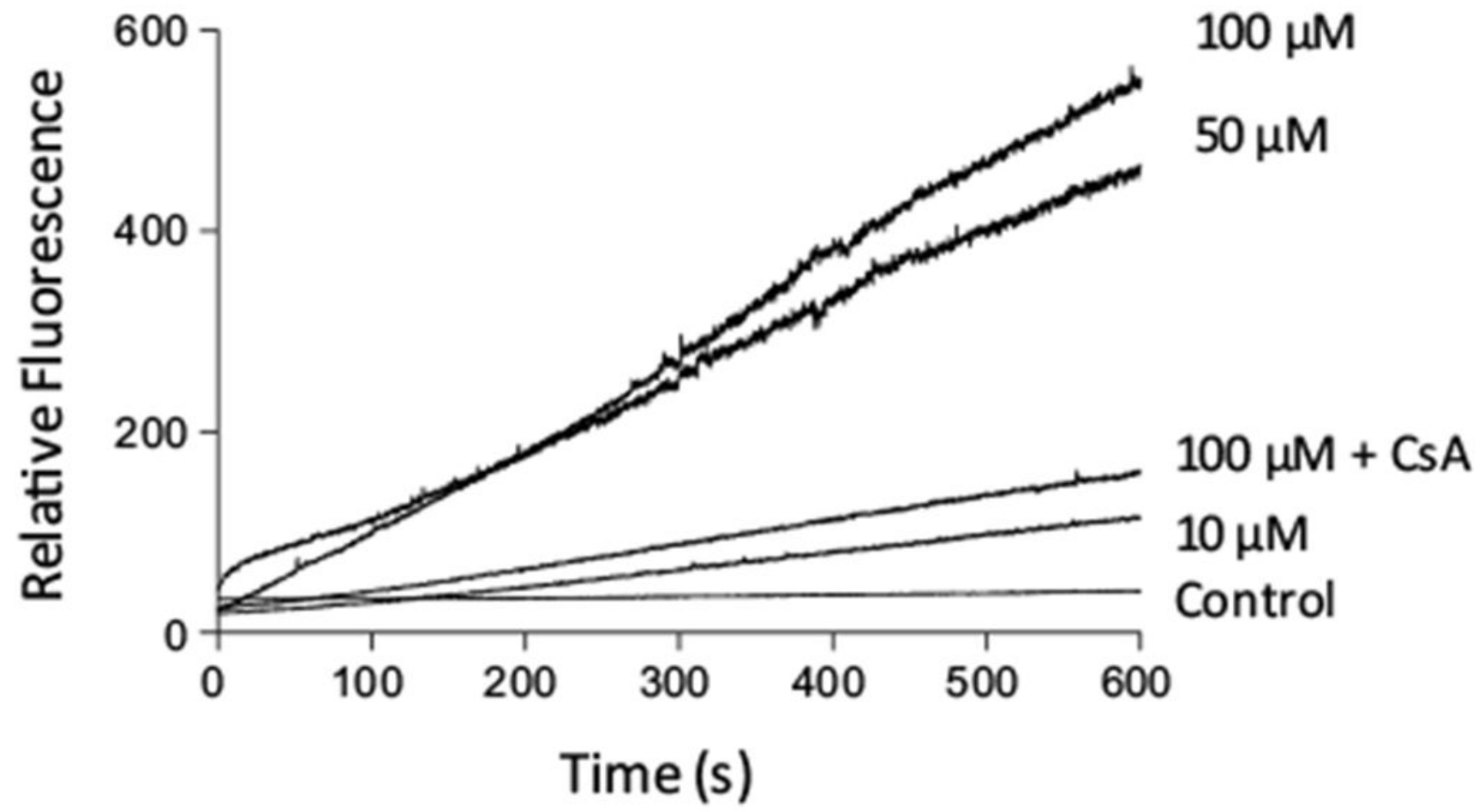

Fig. 6.

Time course of mitochondrial ROS generation in the presence of NO released from complex (Ru-DCBPY), as assessed with $\mathrm{H}_{2}$ DCFDA. Mitochondria $\left(0.5 \mathrm{mg}\right.$ protein $\left.\mathrm{mL}^{-1}\right)$ were incubated in the standard medium described in Fig. 1 , at $30{ }^{\circ} \mathrm{C}$, in the presence of $5 \mu \mathrm{M}$ succinate $+2.5 \mu \mathrm{M}$ rotenone. Plots are representative of at least three experiments with different mitochondrial preparations 

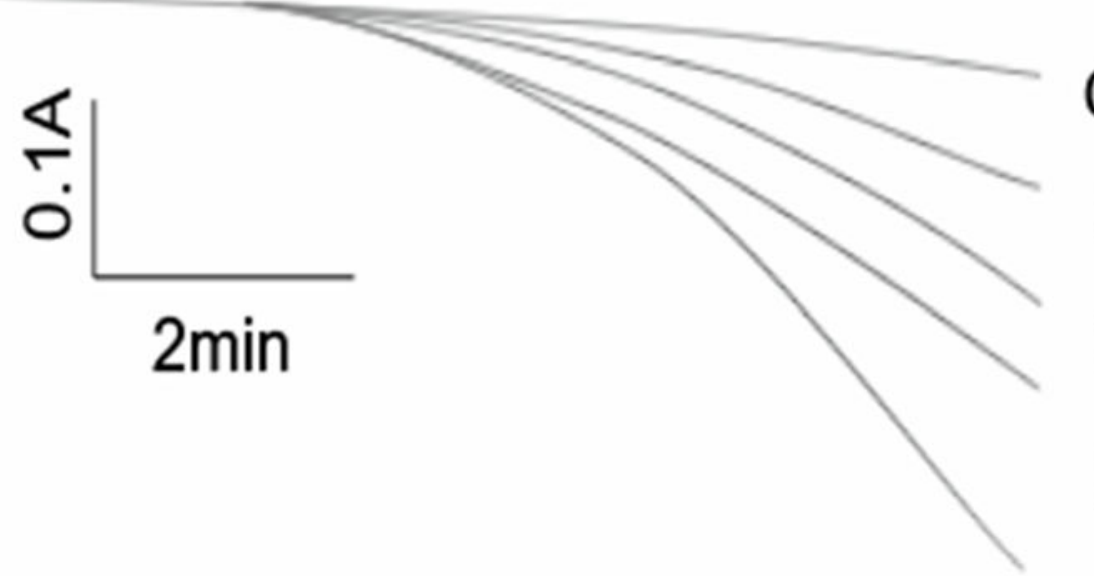

CSA; EGTA; CSA + $50 \mu \mathrm{M}$ Control

$10 \mu \mathrm{M}$

$50 \mu \mathrm{M}$

$100 \mu \mathrm{M}$

Fig. 7.

Time course of mitochondrial swelling induced by NO released from complex (RuDCBPY). Mitochondria $\left(0.5 \mathrm{mg}\right.$ protein $\left.\mathrm{mL}^{-1}\right)$ were incubated in the standard medium described in Fig. 1 , at $30{ }^{\circ} \mathrm{C}$, in the presence of $5 \mu \mathrm{M}$ succinate $+2.5 \mu \mathrm{mol} \mathrm{L}-1$ rotenone. Data are representative of at least three experiments with different mitochondrial preparations 


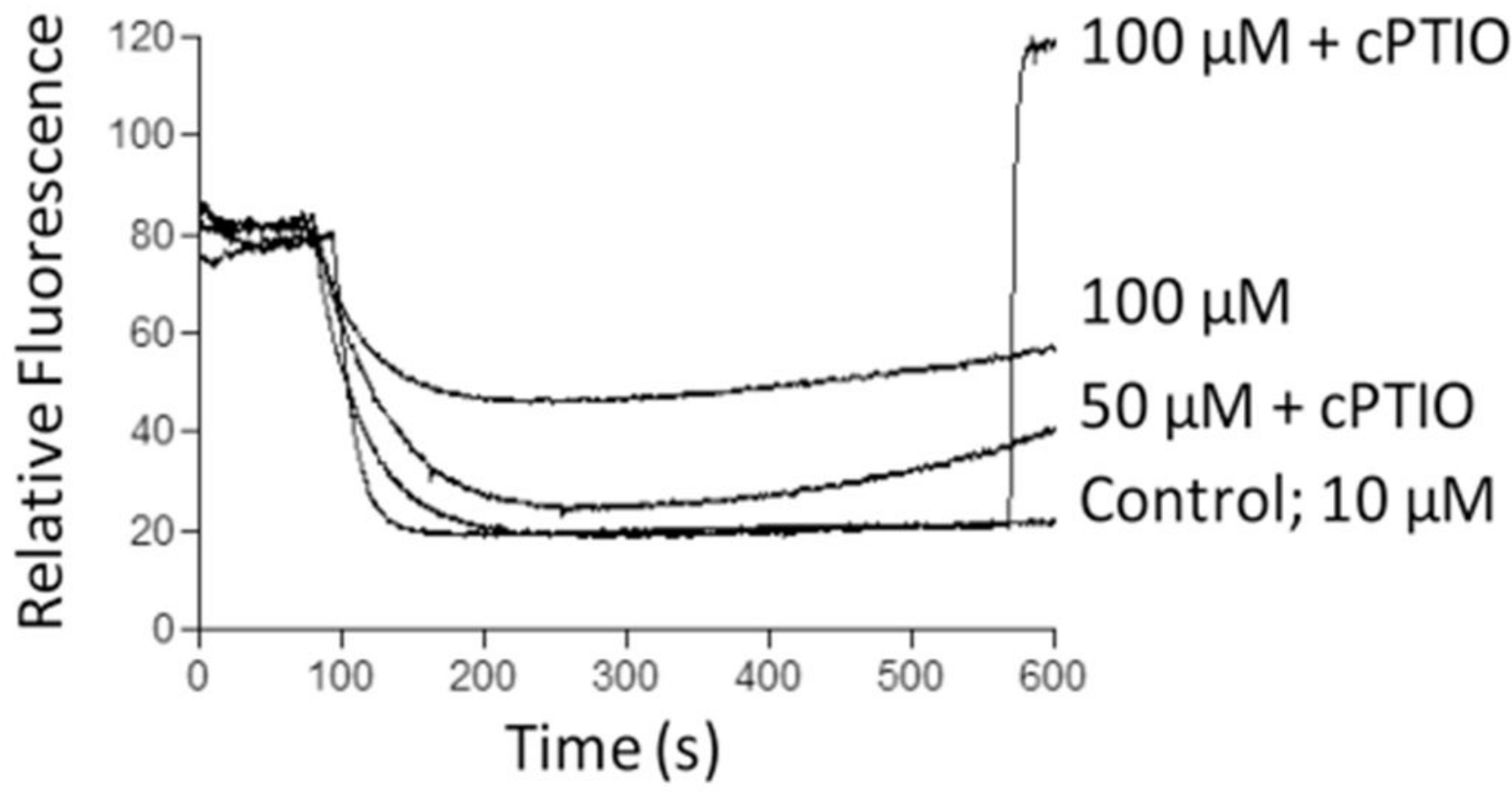

Fig. 8.

Time course of membrane potential induced by NO released from complex (Ru-DCBPY) in succinate-energized mitochondria. Mitochondria $\left(1 \mathrm{mg}\right.$ of protein $\left.\mathrm{mL}^{-1}\right)$ were incubated with $10-100 \mu \mathrm{M}$ of (Ru-DCBPY) in the standard medium, in the presence of $5 \mu \mathrm{M}$ succinate (plus $2.5 \mu \mathrm{mol} \mathrm{L}-1$ rotenone), at $30{ }^{\circ} \mathrm{C}$. Plots are representative of at least three experiments with different mitochondrial preparations 


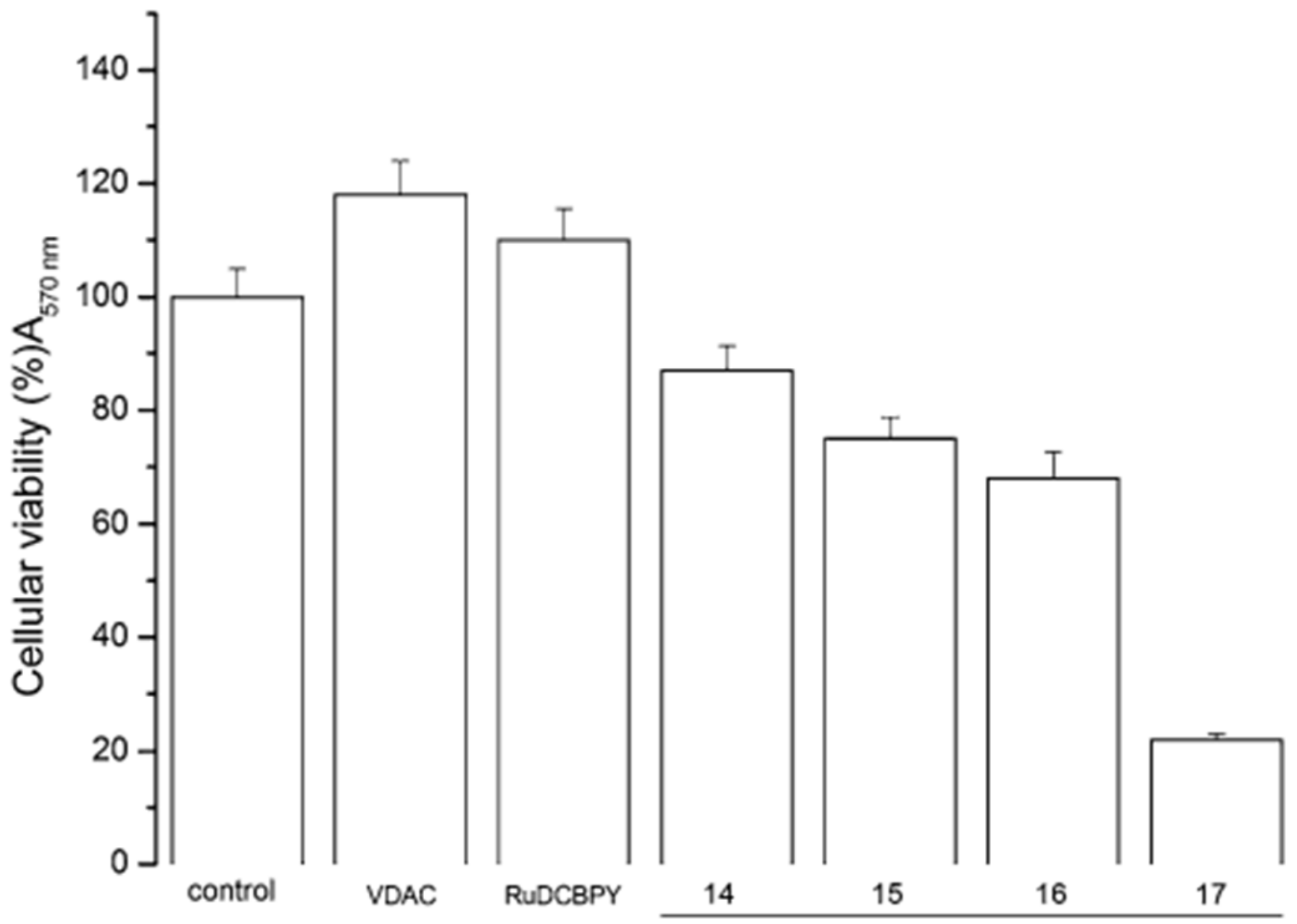

Fig. 9.

MTT cell viability assay. Effects on HepG2 cell viability of follow treatments: control, DMEM cell culture medium; VDAC (IgG anti-VDAC antibody solubilized in DMEM medium); complex (I), ruthenium nitrosyl complex Ru-DCBPY not conjugated with IgG anti-VDAC antibody, e.g., Ru-DCBPY; Fractions 14, 15, 16, and 17 were from the conjugate purification on a Sephadex column, as described in "Materials and methods", (Ru-DCBPY)$\mathrm{IgG}$. The experiments were performed in triplicate, independently, and expressed as the mean and standard deviation 

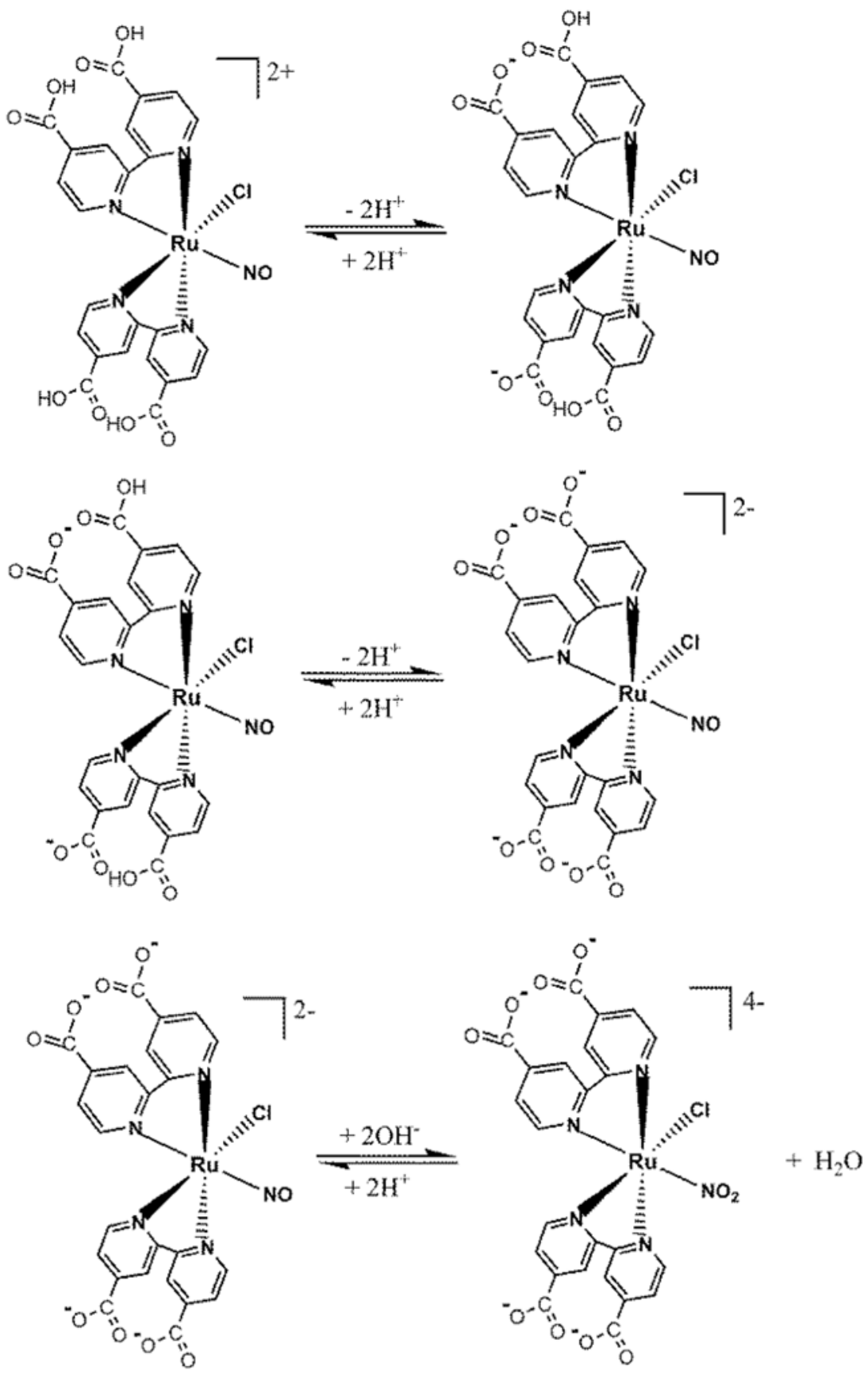

Scheme 1.

Effect of $\mathrm{pH}$ on the chemical composition of $c i s-\left[\mathrm{Ru}(\mathrm{NO}) \mathrm{Cl}\left(\mathrm{dcbpy}-\mathrm{H}_{2}\right)_{2}\right]^{2+}$ complex 
Ramos et al.

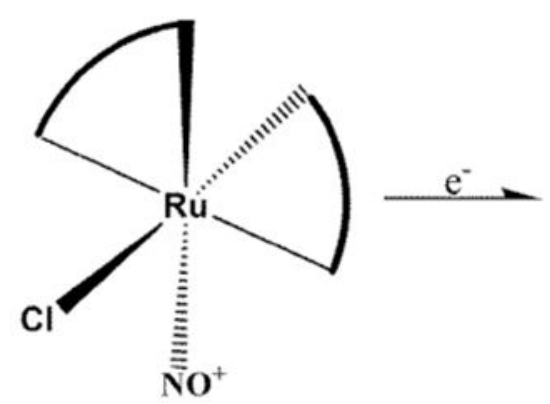

$\mathrm{NO}^{+}$

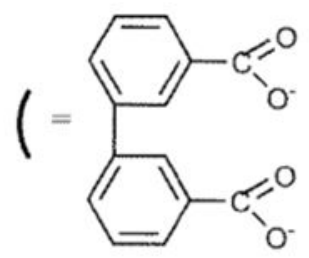

Page 26

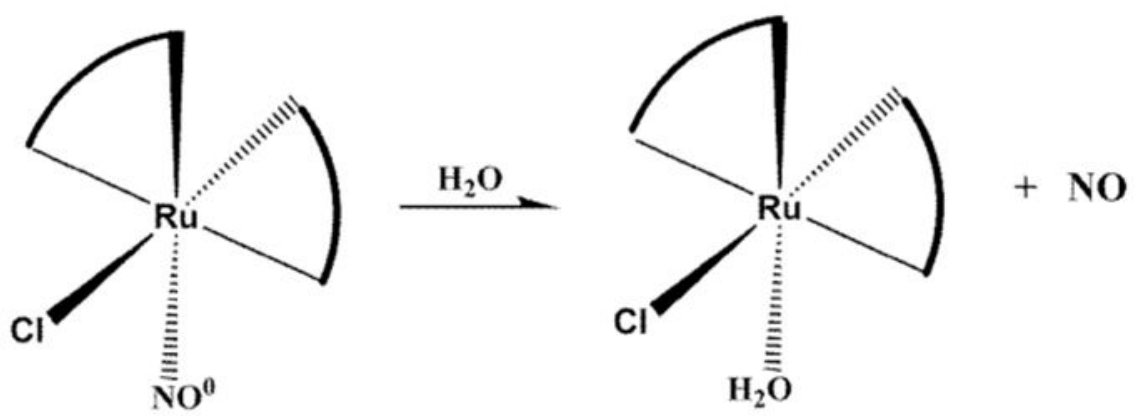

Scheme 2.

Control reduction potential electrolysis of (Ru-DCBPY) specie at $0.1 \mathrm{~V}$ vs. $\mathrm{Ag} / \mathrm{AgCl}$ in $\mathrm{pH}$ 3.0 

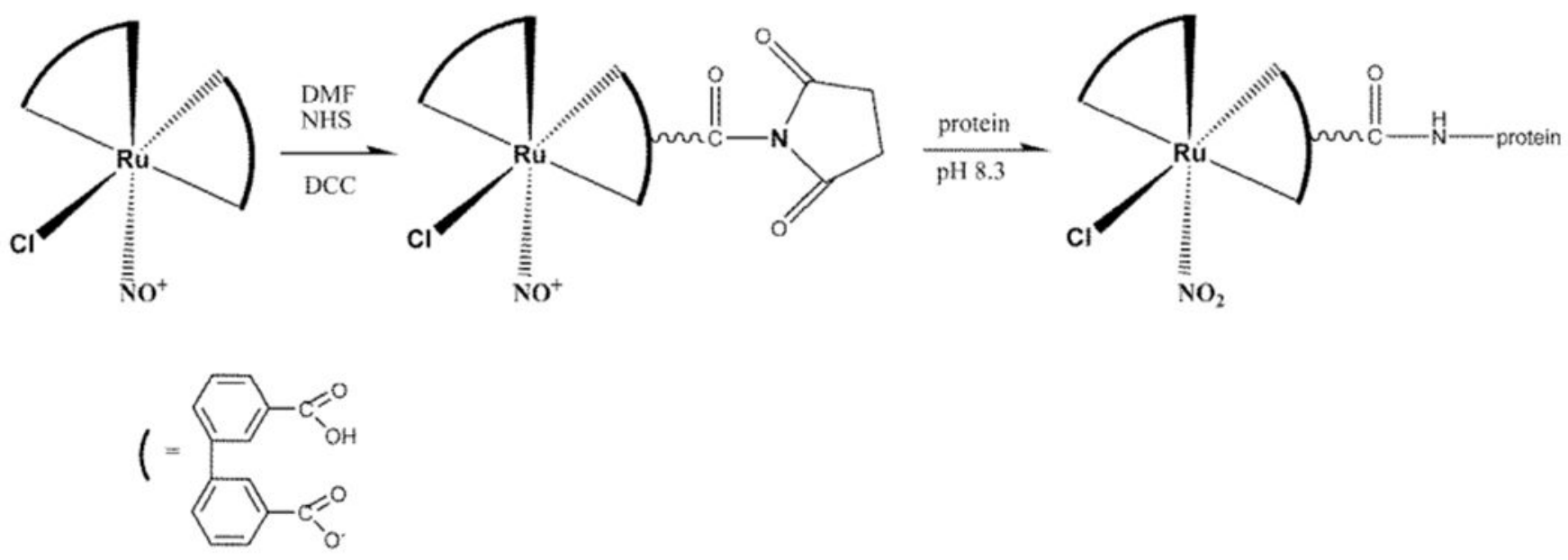

Scheme 3.

Chemical synthesis of the NHS-ester of (Ru-DCBPY) ligation, in basic medium, with IgG anti-VDAC antibody (protein) 


\section{Table 1}

Structural parameters, IR frequencies and relative energies for the different $c i s$ - $\left[\mathrm{Ru}(\mathrm{NO}) \mathrm{Cl}(\mathrm{dcbpy})_{2} \mathrm{H}_{\mathrm{n}}\right]^{\mathrm{n}-2}$ species computed in this computations. The labels employed to identify the protonation sites correspond to the ones in Fig. 1

\begin{tabular}{|c|c|c|c|c|c|c|c|}
\hline$N$ & Species & Protonation pattern & $d_{\mathrm{Ru}-\mathrm{N}(\mathbf{O})}(\stackrel{\mathrm{A}}{)})$ & $d_{\mathrm{N}-\mathrm{O}}(\AA)$ & Ru-N-O & $v_{\mathrm{NO}}{ }^{a}$ & Fraction $^{b}$ \\
\hline \multicolumn{8}{|c|}{ Isolated system } \\
\hline 0 & 1 & - & 1.771 & 1.192 & 173.2 & 1808 & 100 \\
\hline \multirow[t]{4}{*}{1} & 2 & a & 1.790 & 1.194 & 174.3 & 1790 & 78.8 \\
\hline & 3 & $\mathrm{~b}$ & 1.786 & 1.193 & 175.2 & 1797 & 2.5 \\
\hline & 4 & $\mathrm{c}$ & 1.774 & 1.190 & 175.2 & 1811 & 0.8 \\
\hline & 5 & d & 1.783 & 1.193 & 174.0 & 1795 & 18.0 \\
\hline \multirow[t]{6}{*}{2} & 6 & $a-b$ & 1.802 & 1.194 & 173.4 & 1785 & 80.1 \\
\hline & 7 & $\mathrm{a}-\mathrm{c}$ & 1.787 & 1.189 & 175.3 & 1808 & 0.4 \\
\hline & 8 & $\mathrm{a}-\mathrm{d}$ & 1.794 & 1.192 & 174.1 & 1798 & 1.1 \\
\hline & 9 & $\mathrm{~b}-\mathrm{c}$ & 1.783 & 1.188 & 174.6 & 1815 & 0.0 \\
\hline & 10 & $b-d$ & 1.792 & 1.192 & 175.4 & 1797 & 0.5 \\
\hline & 11 & $c-d$ & 1.790 & 1.192 & 175.0 & 1799 & 17.9 \\
\hline \multicolumn{8}{|c|}{ With explicit water molecules } \\
\hline $\mathbf{0}$ & 1 & - & 1.771 & 1.189 & 173.2 & 1819 & 100 \\
\hline \multirow[t]{4}{*}{1} & 2 & a & 1.780 & 1.189 & 173.4 & 1814 & 54.0 \\
\hline & 3 & $\mathrm{~b}$ & 1.777 & 1.188 & 175.0 & 1820 & 9.4 \\
\hline & 4 & $\mathrm{c}$ & 1.768 & 1.187 & 175.1 & 1829 & 4.1 \\
\hline & 5 & $\mathrm{~d}$ & 1.774 & 1.188 & 173.7 & 1819 & 32.5 \\
\hline \multirow[t]{6}{*}{2} & 6 & $a-b$ & 1.793 & 1.191 & 175.3 & 1801 & 53.0 \\
\hline & 7 & $a-c$ & 1.782 & 1.187 & 175.1 & 1819 & 4.5 \\
\hline & 8 & $a-d$ & 1.786 & 1.189 & 174.1 & 1812 & 8.4 \\
\hline & 9 & $\mathrm{~b}-\mathrm{c}$ & 1.779 & 1.186 & 174.6 & 1826 & 1.5 \\
\hline & 10 & $b-d$ & 1.785 & 1.189 & 175.5 & 1813 & 11.0 \\
\hline & 11 & $c-d$ & 1.780 & 1.189 & 175.9 & 1816 & 21.6 \\
\hline
\end{tabular}

J Biol Inorg Chem. Author manuscript; available in PMC 2019 August 01. 


\section{Table 2}

Effects of NO released from complex (Ru-DCBPY) on respiratory parameters of succinate-energized isolated rat liver mitochondria $\left(1 \mathrm{mg}\right.$ protein $\left.\mathrm{mL}^{-1}\right)$ in standard medium

\begin{tabular}{lrlrl}
\hline Mitochondrial parameters & \multicolumn{1}{l}{$\mathbf{d c b p y}(\boldsymbol{\mu M})$} & & \\
\cline { 2 - 5 } & \multicolumn{1}{c}{ Control } & \multicolumn{1}{c}{$\mathbf{1 0}$} & $\mathbf{5 0}$ & \multicolumn{1}{l}{$\mathbf{1 0 0}$} \\
\hline$V 3\left(\mathrm{ng}\right.$ of $\mathrm{O}$ atoms $\left.\mathrm{min}^{-1}\right)$ & $231.5 \pm 6.3$ & $197.0 \pm 11.3$ & $202.2 \pm 1.4$ & $123.6 \pm 7.7$ \\
$V 4\left(\mathrm{ng}\right.$ of $\mathrm{O}$ atoms $\left.\mathrm{min}^{-1}\right)$ & $31.3 \pm 2.2$ & $34.5 \pm 2.1$ & $48.3 \pm 8.1$ & $120 . \pm 8.3^{*}$ \\
$V_{\mathrm{CCCP}}$ & $245.1 \pm 7.4$ & $189.1 \pm 5.3^{*}$ & $250.4 \pm 8.9$ & $255.1 \pm 4.6$ \\
$\mathrm{RCR}$ & $6.4 \pm 1.4$ & $5.8 \pm 1.5$ & $4.3 \pm 0.5$ & $1.3 \pm 0.9^{*}$ \\
$\mathrm{ADP} / \mathrm{O}$ & $2.0 \pm 0.2$ & $1.7 \pm 0.2$ & $1.7 \pm 0.3$ & $1.3 \pm 0.4^{*}$ \\
\hline
\end{tabular}

Values are presented as mean $\pm \operatorname{SEM}(n=3), P<0.05$ vs. control 